\title{
Synthesis and Characterization of Bidentate Isonitrile Iron Complexes
}

\author{
Marion Till, John A. Kelly, Christoph G. P. Ziegler, Robert Wolf,* Tianao Guo, Mark R. Ringenberg, \\ Eugen Lutsker, and Oliver Reiser*
}

Cite This: Organometallics 2021, 40, 1042-1052

Read Online

\section{ACCESS 1}

Џlll Metrics \& More

回国 Article Recommendations

Supporting Information

ABSTRACT: The divalent iron complexes trans- $\left[\mathrm{FeBr}_{2}(\mathrm{BINC})_{2}\right]$, $[\mathrm{Cp} * \mathrm{FeCl}(\mathrm{BINC})]\left(\mathrm{Cp}^{*}=\mathrm{Me}_{5} \mathrm{C}_{5}\right)$, and $\left[\mathrm{FeBr}_{2}\left(\mathrm{CNAr}_{3} \mathrm{NC}\right)_{2}\right]$ with the chelating bis(isonitrile) ligands BINC (bis(2-isocyanophenyl)phenylphosphonate) and $\mathrm{CNAr}_{3} \mathrm{NC}$ (2,2"-diisocyano-3,5,3",5"tetramethyl-1, $1^{\prime}: 3^{\prime}, 1^{\prime \prime}$-terphenyl) have been prepared and characterized. Their subsequent reduction yields the di- and trinuclear compounds $\left[\mathrm{Fe}_{3}(\mathrm{BINC})_{6}\right], \quad[\mathrm{Cp} * \mathrm{Fe}(\mathrm{BINC})]_{2}, \quad\left[\mathrm{Fe}\left(\mathrm{CNAr}_{3} \mathrm{NC}\right)_{2}\right]_{2}$, and $[\mathrm{K}-$ $\left.\left(\mathrm{Et}_{2} \mathrm{O}\right)\right]_{2}\left[\mathrm{Fe}\left(\mathrm{CNAr}_{3} \mathrm{NC}\right)_{2}\right]_{2}$. The molecular structures of all new species were determined by $\mathrm{X}$-ray crystallography and compared to those of
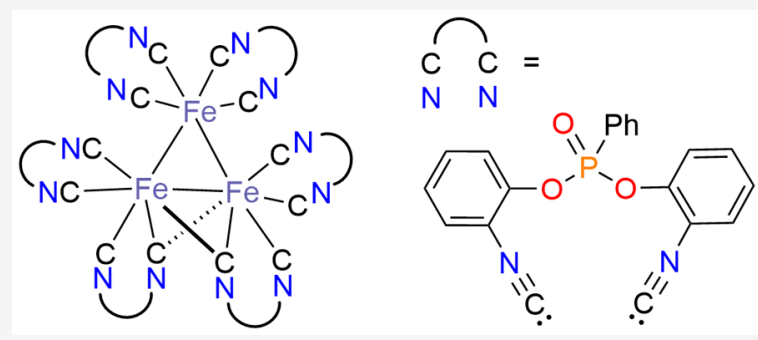
related iron carbonyl complexes, demonstrating that the bidentate isonitrile ligands are capable surrogates for two CO ligands with only minimal distortion of the tetrahedral or octahedral geometry of the parent complexes. The complexes were further characterized by NMR and IR spectroscopy, and the electrochemical properties of selected compounds were analyzed by UV-vis-NIR spectroelectrochemistry.

\section{INTRODUCTION}

With the discovery of isonitriles by Lieke ${ }^{1}$ in 1859 came a new and emerging field within organometallic chemistry. ${ }^{2}$ Isonitriles show stronger $\sigma$-donating character and weaker $\pi$ acceptor properties in comparison to carbon monoxide. However, they feature similar behavior when they coordinate to metals as both terminal and bridging ligands. ${ }^{3,4}$ Isonitriles can be electronically and sterically tuned through modification of their organic substituents, which makes them versatile ligands for metal catalysis. ${ }^{5}$ Chelating bis(isonitriles) confer rigidity to metal complexes, which has been proven to be especially valuable for the design of $3 \mathrm{~d}$-metal complexes with sufficient excited-state lifetimes to efficiently initiate singleelectron-transfer (SET) processes. This approach has been successful for copper, ${ }^{6}$ molybdenum, ${ }^{7}$ and rhenium, ${ }^{8}$ providing alternatives to established but scarce ruthenium- and iridiumbased photocatalysts. ${ }^{9}$

Extending this concept to iron holds the promise of making this metal broadly available for photocatalysis. This is especially challenging, given that excited-state lifetimes of iron complexes are often in the picosecond range and have been reported at best in the low-nanosecond range. ${ }^{10}$ However, there is only limited data available on coordination complexes of iron with bidentate isonitriles, ${ }^{20-23}$ in contrast with monodentate isonitrile iron complexes, which have attracted considerable attention due to the high prevalence of iron carbonyl complexes. ${ }^{11}$ For example, dinuclear iron complexes such as $\left[\mathrm{CpFe}(\mathrm{CNPh})_{2}\right]^{12}\left(\mathrm{~A}, \mathrm{Ph}=\mathrm{C}_{6} \mathrm{H}_{5}\right)$ and
$\left[\mathrm{Fe}_{2}(\mathrm{CNPh})_{9}\right]^{13}$ (B) feature terminal and bridging isonitrile ligands (Figure 1).

The trinuclear compound $\left[\mathrm{Fe}_{3}(\mathrm{CO})_{10}(\mathrm{CNPh})_{2}\right](\mathrm{C})^{14}$ possesses both $\mathrm{CO}$ and monodentate isonitrile ligands, having replaced two of the axial $\mathrm{CO}$ ligands in $\left[\mathrm{Fe}_{3}(\mathrm{CO})_{12}\right]$. Iron isonitrile analogues of $\left[\mathrm{Fe}(\mathrm{CO})_{4}\right]^{2-},\left[\mathrm{Fe}(\mathrm{CNXyl})_{4}\right]^{2-}(\mathrm{Xyl}=$ $\left.2,6-\mathrm{Me}_{2} \mathrm{C}_{6} \mathrm{H}_{3}\right)^{15}$ and $\left[\mathrm{Fe}\left(\mathrm{CNAr}{ }^{\mathrm{Mes} 2}\right)_{4}\right]^{2-}\left(\mathrm{Ar}^{\mathrm{Mes} 2}=2,6-(2,4,6-\right.$ $\left.\left.\mathrm{Me}_{3} \mathrm{C}_{6} \mathrm{H}_{2}\right)_{2} \mathrm{C}_{6} \mathrm{H}_{3}\right),{ }^{16}$ further demonstrate the propensity of monodentate isonitriles to act as surrogates for $\mathrm{CO}$.

In comparison to monodentate isonitrile ligands, the reactivity and coordination chemistry of bidentate isonitriles has been generally unexplored. ${ }^{5}$ Given the linear structure of the isonitrile unit, such ligands need to form much larger chelates relative to the typical $N, N$ - or $P, P$-ligands that are commonly found in five- and six-membered rings. The minimal ring size in a bidentate isonitrile-metal complex was found to be $12 .{ }^{19}$ With this design concept, a number of iron(II) complexes with bidentate isonitrile ligands were realized; representative examples are $\mathbf{D}-\mathbf{G}$ (Figure 1).,20-23

Some of us have previously been interested in the synthesis and reactivity of low-oxidation-state polyarene and alkene ferrates. ${ }^{24}$ Such complexes have been used for various

Received: January 23, 2021

Published: April 7, 2021 


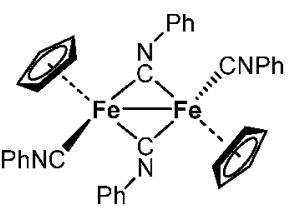

A

Fehlhammer 1980

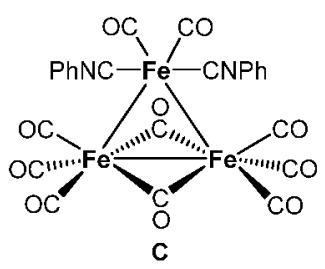

Nicholson 1990

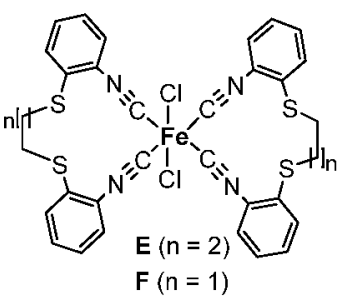

Sakata 1994/2003

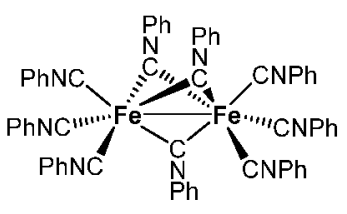

B

Ruiz \& Riera 1992<smiles></smiles>

Kargol \& Angelici 1983

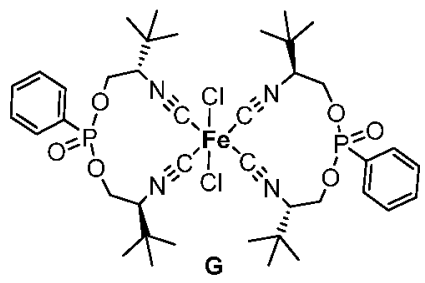

Reiser 2010<smiles>C=Nc1ccccc1OP(=O)(Oc1ccccc1)c1ccccc1N=C</smiles>

BINC

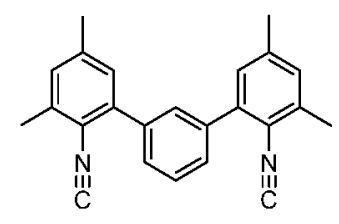

$\mathrm{CNAr}_{3} \mathrm{NC}$
Figure 1. Selected examples of di- and trinuclear iron isonitrile complexes.

applications, including the activation of small molecules (e.g., $\mathrm{P}_{4}$ and $\mathrm{CO}_{2}$ ) and as catalysts for hydrogenation and hydroboration reactions. ${ }^{25}$ Taking advantage of the wellknown ability of isonitriles to stabilize low-oxidation-state transition-metal complexes, ${ }^{15-18,26}$ in combination with imposing rigidity, we were interested in exploring the potential of the aforementioned chelating isonitrile ligands in the stabilization of highly reduced iron complexes. We particularly questioned if polynuclear iron complexes with chelating bis(isonitrile) ligands can still be formed, for which to the best of our knowledge no previous examples have been described in the literature. Here, we report the synthesis and characterization of new iron complexes with the ligands BINC (bis(2-isocyanophenyl)phenylphosphonate) and $\mathrm{CNAr}_{3} \mathrm{NC}$ (2,2" -diisocyano-3,5,3",5"tetramethyl-1, $1^{\prime}: 3^{\prime}, 1^{\prime \prime}$-terphenyl, demonstrating that indeed di- and trinuclear structures can be realized.

\section{RESULTS AND DISCUSSION}

Treating anhydrous $\mathrm{FeBr}_{2}$ with 2 equiv of BINC resulted in the formation of trans- $\left[\mathrm{FeBr}_{2}(\mathrm{BINC})_{2}\right](\mathbf{1})$ as a blue solid in $33 \%$ isolated yield (Scheme 1). Compound 1 displays structural and spectroscopic features similar to those of compounds $\mathbf{D}-\mathbf{G}$
Scheme 1. Synthesis of $\left[\mathrm{FeBr}_{2}(\mathrm{BINC})_{2}\right](1)$ and $\left[\mathrm{Fe}_{3}(\mathrm{BINC})_{6}\right](2)$

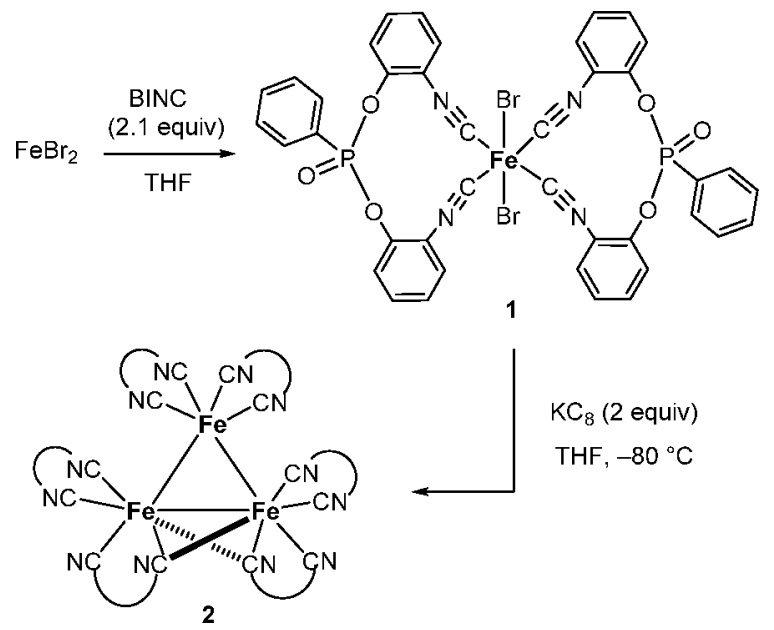

(see Figure S34 in the Supporting Information for a graphical representation of the structure).

Reduction of 1 with an excess of $\mathrm{KC}_{8}$ in THF afforded an orange-brown solution from which brown crystals of $\left[\mathrm{Fe}_{3}(\mathrm{BINC})_{6}\right]$ (2) were isolated in a yield of $26 \%$ by slow diffusion of $n$-hexane into the reaction mixture.

Single-crystal X-ray diffraction (XRD, Figure 2) revealed that 2 crystallizes in the space group $P \overline{1}$ with two molecules in the unit cell. At first glance, the structure of 2 resembles that of $\left[\mathrm{Fe}_{3}(\mathrm{CO})_{12}\right](\mathbf{H})$ with respect to the $\mathrm{Fe} 1-\mathrm{Fe} 2-\mathrm{Fe} 3$ core (Table 1), showing that the the BINC ligand can displace the carbonyl groups without imposing constraints due to its chelating structure. Each atom in the triiron core is

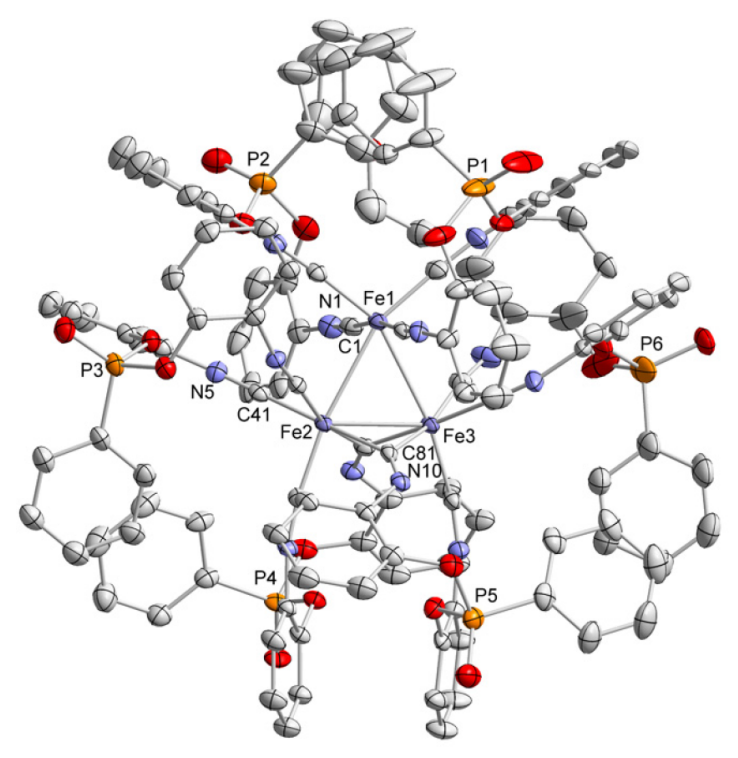

Figure 2. Solid-state molecular structure of the complex $\left[\mathrm{Fe}_{3}(\mathrm{BINC})_{6}\right]$ (2). Ellipsoids are drawn at the $40 \%$ probability level. $\mathrm{H}$ atoms and disorder in the phenyl groups are omitted for clarity. Selected bond lengths (A) and angles (deg): Fe1-C1 1.839(3), C1-N1 1.176(4), Fe2-C81 2.014(3), Fe3-C81 1.945(3), C81-N10 1.235(4), Fe2-C41 1.853(3), C41-N5 1.168(4); Fe2-C81-Fe3 78.10(1), Fe1-Fe2-C81 89.64(8), C81$\mathrm{Fe} 3-\mathrm{Fe} 1$ 91.04(8). $\mathrm{Fe}-\mathrm{Fe}$ distances and $\mathrm{Fe}-\mathrm{Fe}-\mathrm{Fe}$ angles are given in Table 1. 
Table 1. Selected Bond Lengths ( $)$ and Angles (deg) of 2 and $\left[\mathrm{Fe}_{3}(\mathrm{CO})_{12}\right](\mathrm{H})^{a}$

$\begin{array}{lcc} & 2 & {\left[\mathrm{Fe}_{3}(\mathrm{CO})_{12}\right]} \\ \mathrm{Fe} 1-\mathrm{Fe} 2 & 2.682(6) & 2.677(2) \\ \mathrm{Fe} 2-\mathrm{Fe} 3 & 2.495(6) & 2.558(1) \\ \mathrm{Fe} 3-\mathrm{Fe} 1 & 2.685(6) & 2.683(1) \\ \mathrm{Fe} 1-\mathrm{Fe} 2-\mathrm{Fe} 3 & 62.37(2) & 61.6(2) \\ \mathrm{Fe} 2-\mathrm{Fe} 3-\mathrm{Fe} 1 & 62.23(2) & 61.2(2) \\ \mathrm{Fe} 3-\mathrm{Fe} 1-\mathrm{Fe} 2 & 55.41(2) & 57.2(2)\end{array}$

$a_{\text {The data for }} 2$ were collected at $123 \mathrm{~K}$, while the data for $\mathbf{H}$ were collected at room temperature. ${ }^{27}$

coordinated by two BINC ligands, displaying one shorter and two longer $\mathrm{Fe}-\mathrm{Fe}$ bonds ( $\mathrm{Fe} 2-\mathrm{Fe} 32.495(6) \AA ̊$ vs $\mathrm{Fe} 1-\mathrm{Fe} 2$ 2.682(6) $\AA$ and $\mathrm{Fe} 1-\mathrm{Fe} 32.685(6) \AA$ ) resembling an isosceles triangle. The shorter $\mathrm{Fe} 2-\mathrm{Fe} 3$ bond features two bridging isonitrile donor moieties, similar to the case for $\mathbf{H}$ which possesses ten terminal and two bridging carbonyl ligands. ${ }^{27}$ Nevertheless, due to the chelate ring in the bis(isonitrile) ligand the triiron core of 2 shows slightly widened bond angles of 62.37 and $62.23^{\circ}$ for $\mathrm{Fe} 1-\mathrm{Fe} 2-\mathrm{Fe} 3$ and $\mathrm{Fe} 2-\mathrm{Fe} 3-\mathrm{Fe} 1$, respectively, and a more acute angle of $55.41^{\circ}$ for $\mathrm{Fe} 2-\mathrm{Fe} 1-$ $\mathrm{Fe} 3$ in comparison with $\mathbf{H}\left(61.6,61.2\right.$, and $57.2^{\circ}$, respectively).

The ${ }^{31} \mathrm{P}\left\{{ }^{1} \mathrm{H}\right\}$ NMR spectrum of 2 shows only one singlet at $\delta 13.2 \mathrm{ppm}$ in THF- $d_{8}$, indicating a fluxional behavior by fast exchange of the bridging $\mathrm{C} \equiv \mathrm{N}$ units in solution. In agreement with this analysis, only one ${ }^{13} \mathrm{C}\left\{{ }^{1} \mathrm{H}\right\}$ NMR signal is observed for the isonitrile carbon atoms at $\delta 218.7 \mathrm{ppm}$, which is shifted downfield in comparison to the corresponding signal of the free BINC ligand ( $\delta$ 172.4 $\mathrm{ppm})$. The solid-state infrared spectrum of 2 features a broad band centered at $2035 \mathrm{~cm}^{-1}$ assignable to the isonitrile $\nu[\mathrm{CN}]$ stretch, shifted to lower wavenumbers in comparison to the isonitrile $\nu[\mathrm{CN}]$ stretch in $1\left(2122 \mathrm{~cm}^{-1}\right)$. The $\nu[\mathrm{CN}]$ stretching frequency for the divalent complex 1 is similar to that of the free BINC (2126 $\mathrm{cm}^{-1}$ ), as the isonitrile functions essentially as a pure donor ligand. In contrast, compound 2 , with an iron center in the formally zerovalent oxidation state, shows $\nu[\mathrm{CN}]$ stretching frequencies shifted to lower energies, shortened terminal $\mathrm{Fe}-\mathrm{C}$ bond lengths (av. 1.83(1) $\AA$ vs $1.87(4) \AA$ in 1), and slightly more bent $\mathrm{Fe}-\mathrm{C}-\mathrm{N}$ angles $\left(172.5(3)^{\circ}\right.$ vs $176.1(1)^{\circ}$ in 1$)$. When they are taken together, these data indicate substantial $\mathrm{M}(\mathrm{d} \pi) \rightarrow \pi^{*}$ back-bonding in 2 . $^{28}$

The electrochemical behavior of 2 (see Figure S41 in the Supporting Information) was analyzed with UV-vis-NIR spectroelectrochemistry (SEC) in an optically transparent thinlayered electrode (OTTLE) cell. ${ }^{29}$ The cyclic voltammogram showed a single partially reversible oxidation at $E_{\mathrm{pa}}=-0.6 \mathrm{~V}$ versus $\left[\mathrm{FeCp}_{2}\right]^{0 /+}$, which was used as the internal standard for all potentials reported herein unless otherwise noted. The neutral complex could be regenerated at $E_{\mathrm{pc}}=-1.35 \mathrm{~V}$. The SEC for the oxidation process showed that the bands at 350 and $715 \mathrm{~nm}$ were consumed and replaced by a band at $475 \mathrm{~nm}$ with a shoulder at $580 \mathrm{~nm}$. The spectrum of 2 could be regenerated after a cathodic potential of $<1.5 \mathrm{~V}$ was reached. The electrochemical behavior of $\left[\mathrm{Fe}_{3}(\mathrm{CO})_{12}\right]$ in THF was reported to show only irreversible processes. ${ }^{3}$

Other prominent motifs for iron(II) complexes are mononuclear and dinuclear iron carbonyl species such as $\left[\mathrm{CpFeCl}(\mathrm{CO})_{2}\right](\mathrm{I})$, which was first synthesized by Hubbard, ${ }^{31}$ and $\left[\mathrm{CpFe}(\mathrm{CO})_{2}\right]_{2}(\mathrm{~J}) .^{32}$ In the case of $\mathbf{J}$ it was demonstrated that the $\mathrm{CO}$ ligands could be substituted with monodentate isonitrile ligands, resulting in A (Figure 1). Again, we questioned if substitution by the bidentate isonitrile ligand BINC is also tolerated.

With $[\mathrm{Cp} * \mathrm{FeCl}(\text { tmeda })]^{33}$ (Scheme $2 ; \mathbf{K}$, tmeda $=$ tetramethylethylene-1,2-diamine) as the starting material, the

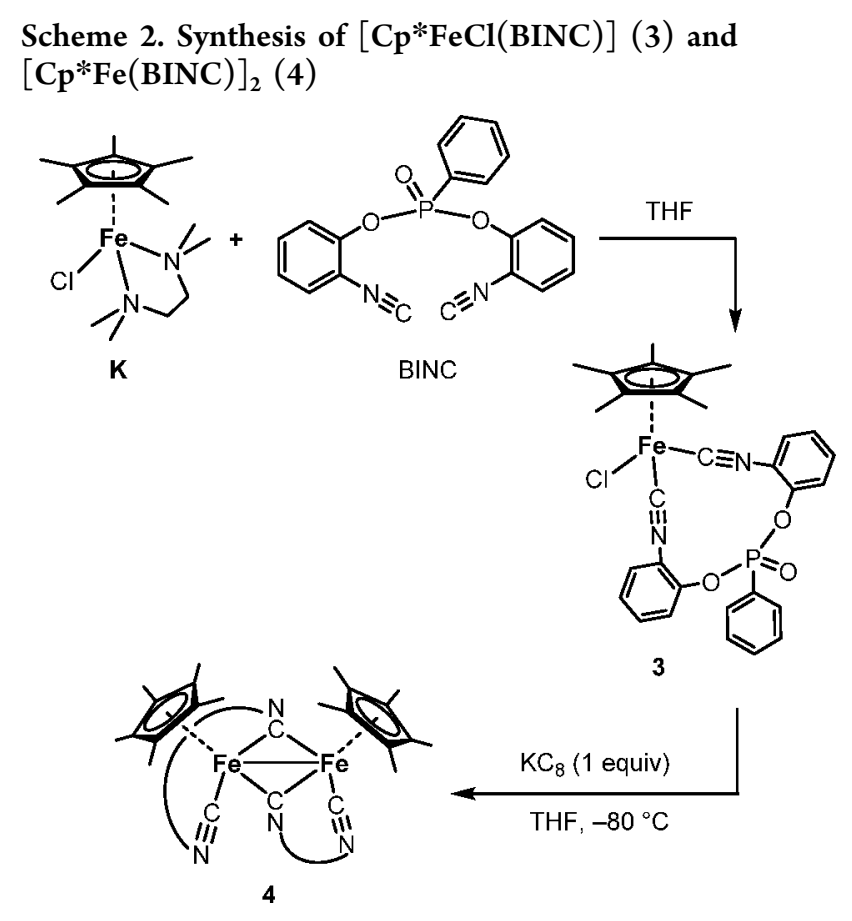

mononuclear $[\mathrm{Cp} * \mathrm{FeCl}(\mathrm{BINC})]\left(3, \mathrm{Cp}^{*}=\mathrm{Me}_{5} \mathrm{C}_{5}\right)$ could be readily synthesized in $82 \%$ yield and fully characterized by NMR/IR spectroscopy and XRD (see Figure S35 in the Supporting Information). The iron atom possesses a distortedtetrahedral geometry, being $\eta^{5}$-coordinated by the $\mathrm{Cp} *$ ligand, the two isonitrile moieties of the BINC ligand, and a chloride ligand. The carbon monoxide analogue I has a similar distorted-tetrahedral geometry in which the chloride and the two CO ligands are sterically repelled by the $\eta^{5}$-coordinated cyclopentadienyl ligand and possess a $\mathrm{C}-\mathrm{Fe}-\mathrm{C}$ angle of $95.6(2)^{\circ}$ and a $\mathrm{C}-\mathrm{Fe}-\mathrm{Cl}$ angle of $90.4(2)^{\circ}$ (vs angles in 3: $\mathrm{C} 1-\mathrm{Fe}-\mathrm{C} 20 \quad 88.4(7)^{\circ}, \mathrm{C} 1-\mathrm{Fe}-\mathrm{Cl} 94.3(6)^{\circ}, \mathrm{C} 20-\mathrm{Fe}-\mathrm{Cl}$ $\left.91.4(6)^{\circ}\right) .{ }^{34}$ The ${ }^{31} \mathrm{P}\left\{{ }^{1} \mathrm{H}\right\}$ NMR spectrum of 3 gives rise to a sharp singlet at $\delta 15.2 \mathrm{ppm}$. The IR spectrum shows two broad bands at 2084 and $2023 \mathrm{~cm}^{-1}$, which are assigned to the symmetrical and asymmetrical $\mathrm{CN}$ stretching vibrations.

The reduction of 3 in THF at low temperatures with 1 equiv of $\mathrm{KC}_{8}$ affords green crystals of 4 in a yield of $18 \%$ after workup and crystallization from THF/n-hexane (Scheme 2). Single-crystal XRD revealed that 4 crystallizes as the cis isomer, in which the $\mathrm{Cp}^{*}$ groups are both coordinated above the $\mathrm{Fe}-$ Fe bond (Figure 3). One $\mathrm{C} \equiv \mathrm{N}$ unit of the BINC ligands links terminally to iron, while the other bridges the iron-iron bond. As a result of the double bridging isonitrile units there is an $\mathrm{Fe}-\mathrm{Fe}$ bond of $2.575 \AA$. The iron-bound bridging isonitrile groups result in an almost planar butterfly motif (Fe1-C20Fe2-C40) with a torsion angle of $7.82^{\circ}$.

The structure of $\mathbf{4}$ is related to that of the phenyl isonitrile complex trans- $\left[\mathrm{CpFe}(\mathrm{CNPh})_{2}\right]_{2}(\mathrm{~A}$, see Figure 1$)$, which was already reported by Fehlhammer in $1980 .{ }^{12}$ In contrast to 4, compound $\mathbf{A}$ crystallizes in a trans/anti configuration with a strictly planar $\mathrm{Fe}_{2} \mathrm{C}_{2}$ core. The $\mathrm{Fe}-\mathrm{Fe}$ bond in $\mathrm{A}$ is $2.523(1) \AA$, 


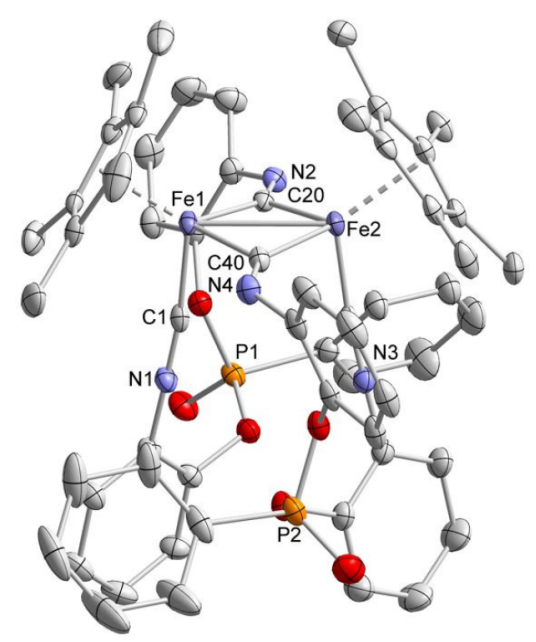

Figure 3. Solid-state molecular structure of the complex $[\mathrm{Cp} * \mathrm{Fe}-$ (BINC) $]_{2}$ (4). Ellipsoids are drawn at the $40 \%$ probability level. $\mathrm{H}$ atoms, solvent molecules, and disorder in the $\mathrm{Cp}^{*}$ groups are omitted for clarity. Selected bond lengths ( $\AA$ ) and angles (deg): Fe1-Fe2 2.575(3), Fe1-C20 1.914(2), Fe2-C20 1.956(2), C20-N2 1.242(2), C21-N3 1.178(2), Fe1-C1 1.787(2), Fe2-C21 $1.795(2) \mathrm{C} 1-\mathrm{N} 1$ 1.176(2), Fe1-C40 1.936(2), Fe2-C40 1.919(2), C40-N4 1.246(2); C1-Fe1-Fe2 95.48(3), C1-Fe1C20 89.88(5), C21-Fe2-Fe1 96.85(5), Fe1-C1-N1 173.08(1), Fe2-C21-N3 173.93(1), C20-Fe1-C40 96.26(7), Fe1-C20-Fe2 83.43(7).

which is shorter than that in complex 4 (2.575(3) $\AA$ ). In both complexes the aryl groups of the bridging isonitrile units show an anti conformation.

The NMR spectroscopic measurements indicate $\mathbf{4}$ is in a cis/ trans isomer equilibrium in THF- $d_{8}$ (Scheme 3 ) that is not affected by temperature changes (see Figure S16 in the Supporting Information).

Scheme 3. cis/trans Isomer Equilibrium of Compound 4 in Solution

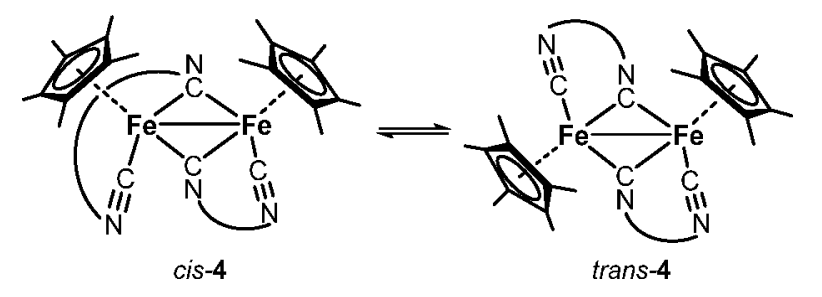

The ratio of the isomers depends on the isolated form of 4; the crystalline product gives rise to the cis isomer as the main component, while for an amorphous powder the trans isomer predominates (see the Supporting Information for spectra).

The occurrence of cis and trans isomers observed for $\mathbf{4}$ is also found in the dinuclear carbonyl analogue $\left[\mathrm{CpFe}(\mathrm{CO})_{2}\right]_{2}$ (J). ${ }^{35}$ X-ray crystal structures for both trans- $\mathrm{J}^{32}$ and cis- $\mathrm{J}^{36,37}$ were obtained. The structure of the cis isomer contains a shortened iron-iron bond (2.531(2) A vs compound 4, Fe1Fe2 2.575(3) A; Table 2) due to the smaller ligands coordinated to the iron centers. ${ }^{36}$ It is noteworthy that the sterically more hindered permethylated derivative $\left[\mathrm{Cp}^{*} \mathrm{Fe}-\right.$ $\left.(\mathrm{CO})_{2}\right]_{2}^{38}(\mathrm{~L})$ appears to exist exclusively as the trans isomer, although the cis configuration has been observed as a shortlived, photogenerated species. ${ }^{37}$ In contrast, 4 exists both as the cis and trans isomers in solution. Nevertheless, the structural parameters of $\mathbf{A}, \mathbf{J}, \mathbf{L}$, and $\mathbf{4}$ are similar. This shows that the exchange of the ancillary ligands ( $\mathrm{Cp}$ vs $\mathrm{Cp}$ *, and $\mathrm{CO}$ vs $\mathrm{CNPh}$ and $\mathrm{BINC}$ ) influences the solution behavior, but it does not strongly affect $\mathrm{Fe}-\mathrm{C}$ and $\mathrm{C}-\mathrm{N}$ bond lengths and $\mathrm{Fe}-\mathrm{C}-\mathrm{N}$ angles.

The electrochemical behavior of 4 in $0.1 \mathrm{M} \mathrm{nBu}_{4} \mathrm{NPF}_{6} / \mathrm{THF}$ showed a partially reversible oxidation wave at $E_{\mathrm{pa}}=-0.7 \mathrm{~V}$ versus $\left.[\mathrm{FeCp}]_{2}\right]^{+/ 0}$ and two irreversible processes at $E_{\mathrm{pa}}=-0.35$ and 0.05 V. SEC of 4 showed that the bands at 600 and 390 $\mathrm{nm}$ decreased upon oxidation, and the process was irreversible (Figure S42 in the Supporting Information). In contrast, the $\mathrm{CV}$ of compound 4 in $\mathrm{CH}_{2} \mathrm{Cl}_{2}$ (Figure S43 in the Supporting Information) showed more resolved redox transitions at -0.7 , $-0.15,0.3$, and $0.65 \mathrm{~V}$. No reduction signal was observed. These transitions were partially reversible according to the UV-vis SEC spectrum, which showed that the absorption bands at 310 and $370 \mathrm{~nm}$ were consumed and a band at 290 $\mathrm{nm}$ appeared. Upon further oxidation the band at $600 \mathrm{~nm}$ was consumed and the band at $290 \mathrm{~nm}$ coalesced.

In hopes of isolating isonitrile ferrate complexes with greater kinetic shielding, BINC was substituted for the bulkier bidentate chelating isonitrile $\mathrm{CNAr}_{3} \mathrm{NC}^{7}$ The addition of 2 equiv of $\mathrm{CNAr}_{3} \mathrm{NC}$ to a solution of anhydrous $\mathrm{FeBr}_{2}$ in THF affords an orange suspension, from which $\left[\mathrm{FeBr}_{2}\left(\mathrm{CNAr}_{3} \mathrm{NC}\right)_{2}\right]$ (5) can be isolated as orange crystals in $55 \%$ yield after crystallization from $\mathrm{CH}_{2} \mathrm{Cl}_{2} / n$-hexane (Scheme 4). The solid-state molecular structure of $\mathbf{5}$ shows a distorted-octahedral geometry at the iron center with a cis configuration of the bromido ligands ( $\mathrm{Br} 1-\mathrm{Fe} 1-\mathrm{Br} 2$ $92.12(2)^{\circ}$; see the Supporting Information for a graphical representation of the structure and further characterization details).

Reduction of $\mathbf{5}$ in THF at low temperature with 2 equiv of $\mathrm{KC}_{8}$ (Scheme 4) results in an orange-red solution from which dark red crystals of $\left[\mathrm{Fe}\left(\mathrm{CNAr}_{3} \mathrm{NC}\right)_{2}\right]_{2}(6)$ were isolated in a

Table 2. Comparison of Selected Bond Lengths $(\AA)$ and Angles (deg) of Compound 4, cis- $\left[\mathrm{CpFe}(\mathrm{CO})_{2}\right]_{2}(\mathrm{~J}){ }^{36}$ trans- $^{3}$ $\left[\mathrm{Cp} * \mathrm{Fe}(\mathrm{CO})_{2}\right]_{2}(\mathrm{~L}),^{39}$ and $\left[\mathrm{CpFe}(\mathrm{CNPh})_{2}\right]_{2}(\mathrm{~A})^{12}$

$\begin{array}{llllc} & \mathbf{4} & \mathbf{J} & \mathbf{L} & \mathbf{A} \\ \mathrm{Fe} 1-\mathrm{Fe} 2 & 2.575(3) & 2.531(2) & 2.560(1) & 2.523(1) \\ \mathrm{Fe} 1-\mathrm{C}_{\text {terminal }} & 1.787(2) & 1.730(7) & 1.753(3) & 1.775(6) \\ \mathrm{C}_{\text {terminal }}-\mathrm{N} / \mathrm{O} & 1.176(2) & 1.159(9) & 1.154(3) & 1.161(8) \\ \mathrm{Fe} 1-\mathrm{C}_{\text {bridged }} & 1.914(2) & 1.918(7) & 1.936(2) & 1.934(6) \\ \mathrm{Fe} 2-\mathrm{C}_{\text {bridged }} & 1.956(2) & 1.908(7) & 1.936(2) & 1.905(6) \\ \mathrm{C}_{\text {bridged }}-\mathrm{N} / \mathrm{O} & 1.242(2) & 1.178(9) & 1.172(3) & 1.242(8) \\ \mathrm{C}_{\text {terminal }}-\mathrm{Fe} 1-\mathrm{C}_{\text {briged }} & 89.88(5) & 92.3(3) & 95.2(1) & 178.4(4) \\ \text { Fe1- } \mathrm{C}_{\text {terminal }}-\mathrm{N} / \mathrm{O} & 173.08(1) & 176.5(8) & 175(8) & 178\end{array}$


Scheme 4. Synthesis of $\left[\mathrm{FeBr}_{2}\left(\mathrm{CNAr}_{3} \mathrm{NC}\right)_{2}\right](5)$, $\left[\mathrm{Fe}\left(\mathrm{CNAr}_{3} \mathrm{NC}\right)_{2}\right]_{2}(6)$, and $\left[\mathrm{K}_{(}\left(\mathrm{Et}_{2} \mathrm{O}\right)\right]_{2}\left[\mathrm{Fe}\left(\mathrm{CNAr}_{3} \mathrm{NC}\right)_{2}\right]_{2}$ (7)

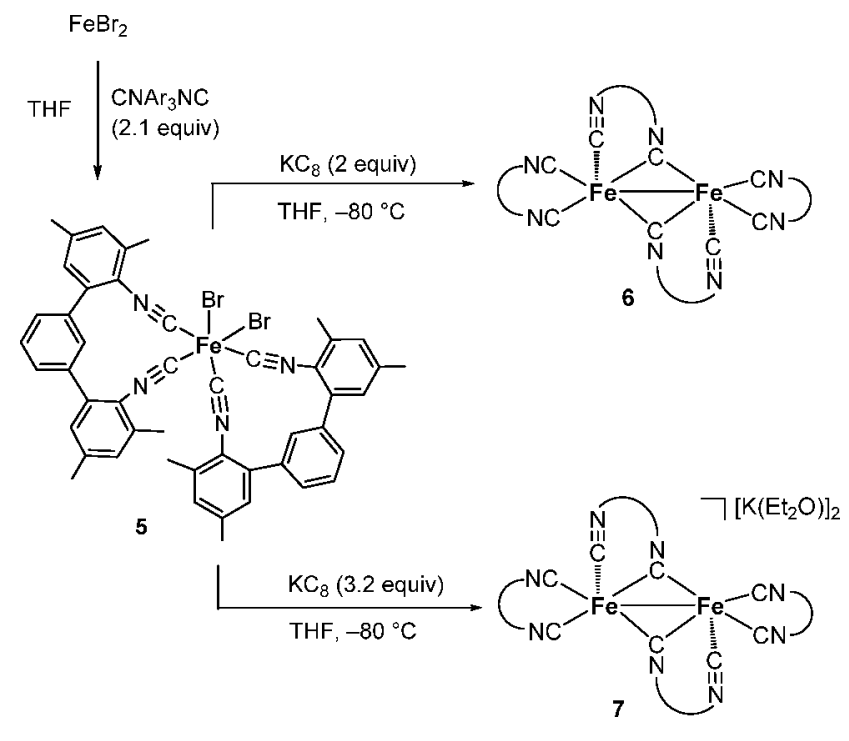

yield of $12 \%$. The ${ }^{1} \mathrm{H}$ NMR spectra and two-dimensional experiments $\left({ }^{1} \mathrm{H},{ }^{1} \mathrm{H}-\mathrm{NOESY}\right)$ show that compound $\mathbf{6}$ is isolated in an equilibrium with one main isomer (cis isomer; see the solid-state molecular structure in Figure 4) and two other species (presumably isomers) with minor populations (see the Supporting Information for spectra).

Single-crystal XRD of 6 confirms the formation of a dimeric iron complex with four $\mathrm{CNAr}_{3} \mathrm{NC}$ isonitrile ligands, two of which are bridging the iron-iron bond. Compound 6 features a relatively short metal-metal bond $(2.434(6) \AA$ ) because of the bridging isonitrile ligands and assumes a butterfly structural motif. The $\mathrm{Fe} 1-\mathrm{C} 25-\mathrm{Fe} 2-\mathrm{C} 49$ torsion angle is $17.9^{\circ}$, which indicates the $\mathrm{Fe}-\mathrm{C}-\mathrm{Fe}-\mathrm{C}$ moiety is nearly planar.
A structural arrangement comparable to that of 6 is the structure of the unsaturated dinuclear iron carbonyl complex $\left[\mathrm{Fe}_{2}(\mathrm{CO})_{8}\right](\mathbf{M})$, which was first observed in 1971 by Poliakoff and Turner as one of the main products from the lowtemperature photolysis of $\left[\mathrm{Fe}_{2}(\mathrm{CO})_{9}\right]$ conducted in $\mathrm{CO}$ matrixes. ${ }^{40,41}$ On the basis of infrared spectroscopic measurements the CO-bridged and unbridged isomers of $\mathbf{M}$ were proposed. ${ }^{40}$ The calculated iron-iron bond length $(2.482 \AA$, Table 3, BP86/TZVP) of the singlet state of $\mathbf{M}$ with $C_{s}$

Table 3. Comparison of Selected Bond Lengths $(\AA)$ and Angles (deg) (Average Values) of 6 and $\left[\mathrm{Fe}_{2}(\mathrm{CO})_{8}\right]\left(\mathrm{M}^{40}\right)^{a}$

\begin{tabular}{llc} 
& \multicolumn{1}{c}{$\mathbf{6}$} & $\mathbf{M}$ \\
$\mathrm{Fe}-\mathrm{Fe}$ & $2.434(6)$ & 2.482 \\
$\mathrm{Fe}-\mathrm{C}_{\text {bridged }}$ & 1.939 & 1.982 \\
$\mathrm{C}_{\text {bridged }}-\mathrm{N} / \mathrm{O}$ & 1.240 & 1.177 \\
$\mathrm{Fe}-\mathrm{C}_{\text {terminal }}$ & 1.848 & 1.802 \\
$\mathrm{C}_{\text {terminal }}-\mathrm{N} / \mathrm{O}$ & 1.171 & 1.154 \\
$\mathrm{Fe}-\mathrm{C}_{\text {terminal }}-\mathrm{N} / \mathrm{O}$ & 174.88 & 178.00
\end{tabular}

${ }^{a}$ Optimized singlet geometry in $C_{s}$ symmetry (BP86/TZVP).

symmetry (global minimum) matches with the symmetry (two bridged $\mathrm{CO}$ units) and bond lengths of the solid-state molecular structure of 6 (Fe1-Fe2 2.434(6) $\AA$ ).

The heightened stability and analogous nature of 6 in comparison to $\mathbf{M}$ allows for the latter's structural realization, something not possible previously due to its inherent instability. As expected for CN-bridged 6 with $C_{s}$ symmetry, an analysis of the DFT calculated $\mathrm{CN}$ stretching frequencies determined six IR-active modes (for a comparison of the calculated IR spectra of $\mathbf{M}$ and $\mathbf{6}$, see the Supporting Information). The solid-state IR spectrum of $\mathbf{6}$ features two specific $\nu[\mathrm{CN}]$ bands at 2070 and $2022 \mathrm{~cm}^{-1}$ (broad bands) for the terminally and bridged coordinated isonitrile units, respectively. These data are in good agreement with the DFT
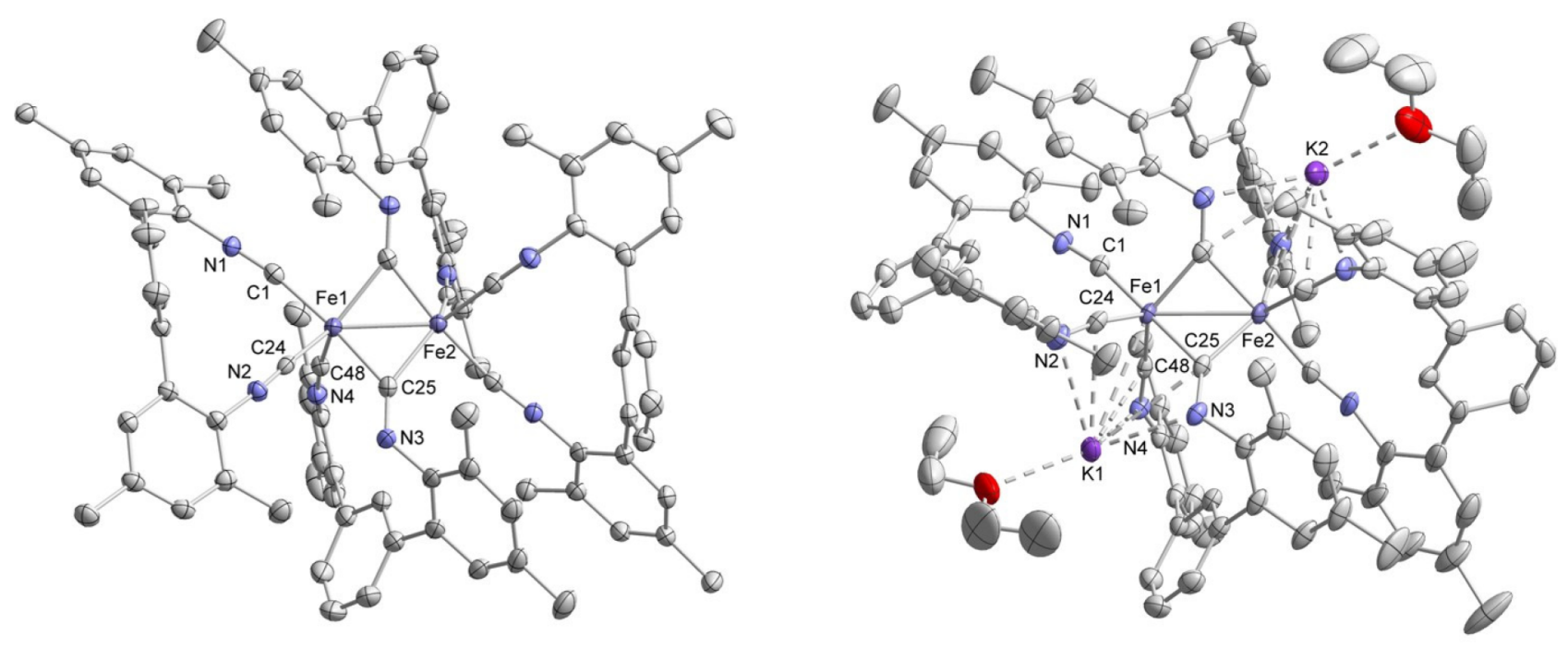

Figure 4. Solid-state molecular structures of $\left[\mathrm{Fe}\left(\mathrm{CNAr}_{3} \mathrm{NC}\right)_{2}\right]_{2}(6$, on the left $)$ and $\left[\mathrm{K}\left(\mathrm{Et}_{2} \mathrm{O}\right)\right]_{2}\left[\mathrm{Fe}\left(\mathrm{CNAr} \mathrm{CNC}_{2}\right]_{2}\right.$ (7, on the right). Ellipsoids are drawn at the $40 \%$ probability level. $\mathrm{H}$ atoms and solvent molecules are omitted for clarity. Selected bond lengths ( $\AA$ ) and angles (deg) of 6 : Fe1Fe2 2.434(6), Fe1-C1 1.835(3), C1-N1 1.165(4), Fe1-C25 1.977(3), Fe2-C25 1.900(3), C25-N3 1.244(4), Fe1-C24 1.860(3), C24-N2 1.176(4), Fe2-C48 1.800(3), C48-N4 1.186(4); Fe1-C25-Fe2 77.73(1), C1-Fe1-C24 87.39(1), Fe1-C1-N1 178.3(3). Selected bond lengths $(\AA)$ and angles (deg) of 7: Fe1-Fe2 2.552(8), Fe1-C1 1.747(5), Fe1-C24 1.838(5), Fe1-C25 1.951(4), Fe2-C25 1.963(4), Fe2-C48 1.789(4), Fe1-K1 3.439(1), Fe2-K2 3.410(1), C1-N1 1.214(9), C24-N2 1.176(6), C25-N3 1.266(5), C48-N4 1.206(5), Fe1-C25-Fe2 81.38(2), Fe1-C1-N1 146.0(6), Fe1-C24-N2 170.7(4), Fe1-C25-N3 142.9(3), Fe2-C25-N3 135.2(3). 
calculated values (see the Supporting Information for further details).

It was previously reported that when monodentate isonitrile ligands were used it was not possible to isolate a dinuclear iron complex bearing eight ligands. An example is $\left[\mathrm{Fe}_{2}(\mathrm{CNPh})_{9}\right]$ (B, Fe-Fe 2.458(1) A; see Figure 1), which is synthesized in a manner comparable to that of $\mathbf{6}$ except partial decomposition must occur to provide an extra isonitrile ligand. ${ }^{13}$ This result shows that the use of the sterically demanding bidentate ligand $\mathrm{CNAr}_{3} \mathrm{NC}$ is key to the successful stabilization of $\mathbf{6}$, allowing for the isolation of a dinuclear iron complex with a lower coordination number.

When the reduction of 5 is repeated with 3 equiv of finely ground $\mathrm{KC}_{8}$ instead of 2 equiv in THF at $-80^{\circ} \mathrm{C}$, a brownish orange solution forms from which $\left[\mathrm{K}\left(\mathrm{Et}_{2} \mathrm{O}\right)\right]_{2}[\mathrm{Fe}-$ $\left.\left(\mathrm{CNAr}_{3} \mathrm{NC}\right)_{2}\right]_{2}(7)$ can be isolated as a black solid in $46 \%$ yield by crystallization from $\mathrm{Et}_{2} \mathrm{O}$ (Scheme 4 ). The solid-state molecular structure of 7 shows a motif similar to that for complex 6 . The iron-iron bond is bridged by two isonitrile units, and the other ligands coordinate terminally to the iron centers. In the solid state, 7 is a contact-ion pair with significant interactions between the potassium and bridging isonitrile units.

The dinuclear dianionic complex $\left[\mathrm{Fe}_{2}(\mathrm{CO})_{8}\right]^{2-}(\mathbf{N})$, which was first reported by Hieber and Brendel, ${ }^{42}$ is the carbon monoxide analogue of compound 7. The solid-state structures of $\mathbf{N}$ feature different coordination modes depending on the counterion used. Single-crystal XRD of [ $\mathrm{Na}$ $\left.(\mathrm{DMF})_{3}\right]_{2}\left[\mathrm{Fe}_{2}(\mathrm{CO})_{8}\right]$ (Na-N) shows no bridging CO ligands, explaining why the $\mathrm{Fe}-\mathrm{Fe}$ bond is significantly longer $(2.804(1) \AA)$ than the metal-metal bond in $7(\mathrm{Fe}-\mathrm{Fe}$ $2.552(8) \AA) .{ }^{43}$ The solid-state structure of [Li$\left.(\mathrm{THF})_{3}\right]_{2}\left[\mathrm{Fe}_{2}(\mathrm{CO})_{8}\right](\mathrm{Li}-\mathrm{N}){ }^{44}$ in which the lithium atoms are bonded to the oxygen atoms of bridging $\mathrm{CO}$ groups, shows the same symmetry $\left(C_{2 v}\right)$ and coordination motif as for compound 7 , which results in similar bond lengths (Table 4 ,

Table 4. Comparison of Selected Bond Lengths $(\AA)$ and Angles (deg) of $7,\left[\mathrm{Li}(\mathrm{THF})_{3}\right]_{2}\left[\mathrm{Fe}_{2}(\mathrm{CO})_{8}\right](\mathrm{Li}-\mathrm{N}),{ }^{44}$ and $\left[\mathrm{Na}(\mathrm{DMF})_{3}\right]_{2}\left[\mathrm{Fe}_{2}(\mathrm{CO})_{8}\right](\mathrm{Na}-\mathrm{N})^{43}$

\begin{tabular}{lccc} 
& 7 & {$[\mathrm{Li}-\mathrm{N}]$} & {$[\mathrm{Na}-\mathrm{N}]$} \\
$\mathrm{Fe}-\mathrm{Fe}$ & $2.552(8)$ & $2.551(1)$ & $2.804(1)$ \\
$\mathrm{Fe}-\mathrm{C}_{\text {bridged }}$ & $1.951(4)$ & $1.929(8)$ & \\
$\mathrm{C}_{\text {bridged }}-\mathrm{N} / \mathrm{O}$ & $1.266(6)$ & $1.216(9)$ & \\
$\mathrm{Fe}-\mathrm{C}_{\text {terminal }}$ & $1.838(5)$ & $1.765(8)$ & $1.781(2)$ \\
$\mathrm{C}_{\text {terminal }}-\mathrm{N} / \mathrm{O}$ & $1.176(6)$ & $1.164(1)$ & $1.158(2)$ \\
$\mathrm{Fe}-\mathrm{C}_{\text {terminal }}-\mathrm{N} / \mathrm{O}$ & $170.7(4)$ & $177.5(7)$ & $176.8(2)$ \\
\hline
\end{tabular}

2.551(1) $\AA$ vs 2.552(8) $\AA$ for 7). Because of the bridging CO/ isonitrile ligands, complexes $\mathrm{Li}-\mathrm{N}$ and 7 both assume a butterfly structural motif and show similar $\mathrm{Fe}-\mathrm{C}-\mathrm{Fe}-\mathrm{C}$ torsion angles of $40.6(3)^{\circ}$ for $\mathrm{Li}-\mathrm{N}$ and $38.5(2)^{\circ}$ for 7 .

\section{CONCLUSION}

We have reported the synthesis and characterization of isonitrile analogues of the classic tri- and dinuclear iron carbonyl complexes. The reduction of the iron(II) precursors trans-[FeBr $\left.{ }_{2}(\mathrm{BINC})_{2}\right]$ (1), [Cp* $\left.\mathrm{FeCl}(\mathrm{BINC})\right]$ (3) and $\left[\mathrm{FeBr}_{2}\left(\mathrm{CNAr}_{3} \mathrm{NC}\right)_{2}\right]$ (5) led to oligonuclear iron compounds with chelating bidentate isonitrile ligands. $\left[\mathrm{Fe}_{3}(\mathrm{BINC})_{6}\right]$ (2) possesses a triangular iron arrangement that is comparable to the structural motif of $\left[\mathrm{Fe}_{3} \mathrm{CO}_{12}\right]$ and has been shown to have fluxional behavior with the bridging and terminal coordinated isonitrile units in solution. The reduction of compound 3 resulted in the dimeric heteroleptic complex $[\mathrm{Cp} * \mathrm{Fe}(\mathrm{BINC})]_{2}$ (4) as a cis/trans isomer mixture. The reduction of 5 bearing a bulkier isonitrile ligand results in $\left[\mathrm{Fe}\left(\mathrm{CNAr}_{3} \mathrm{NC}\right)_{2}\right]_{2}(6)$ and $\left[\mathrm{K}\left(\mathrm{Et}_{2} \mathrm{O}\right)\right]_{2}\left[\mathrm{Fe}\left(\mathrm{CNAr}_{3} \mathrm{NC}\right)_{2}\right]_{2}(7)$, both possessing a butterfly arrangement. In contrast to its $\mathrm{CO}$ analogue $\left[\mathrm{Fe}_{2}(\mathrm{CO})_{8}\right]$, compound $\mathbf{6}$ is stable and isolable at room temperature. A detailed comparison of the spectroscopic and structural parameters of complexes 4-7 to mono(isonitrile) and $\mathrm{CO}$ analogues shows that replacing these monodentate ligands with bidentate isonitrile molecules, such as BINC and $\mathrm{CNAr}_{3} \mathrm{NC}$, does not dramatically affect the molecular or electronic structures. Thus, future investigations will be aimed at the synthesis of further highly reduced ferrate complexes and their utilization for electro- or photocatalysis, where the stable coordination of bidentate (chelating) isonitrile ligands might be beneficial.

\section{EXPERIMENTAL SECTION}

General Procedures. All experiments were performed under an atmosphere of dry argon (Argon 4.6, Linde) using standard Schlenk line techniques, a MBraun UniLab Glovebox, or a GS Glovebox (GS117717). Solvents were dried and degassed with the MBraun SPS800 solvent-purification system. THF, diethyl ether, and DCM were stored over molecular sieves $(3 \AA)$. $n$-Hexane was stored over a potassium mirror. Deuterated tetrahydrofuran was purchased from Sigma-Aldrich and used as received.

Elemental analyses were determined by the analytical department of the University of Regensburg with a Micro Vario Cube (Elementar).

NMR Spectroscopy. NMR spectra were recorded on Bruker Avance $300(300 \mathrm{MHz})$ and Bruker Avance $400(400 \mathrm{MHz})$ spectrometers at $300 \mathrm{~K}$ if not stated otherwise. ${ }^{1} \mathrm{H}$ and ${ }^{13} \mathrm{C}\left\{{ }^{1} \mathrm{H}\right\}$ spectra were referenced internally to residual solvent resonances, while ${ }^{31} \mathrm{P}\left\{{ }^{1} \mathrm{H}\right\}$ spectra were referenced externally to $85 \% \mathrm{H}_{3} \mathrm{PO}_{4}(\mathrm{aq})$. The assignment of ${ }^{1} \mathrm{H}$ and ${ }^{13} \mathrm{C}$ NMR signals was confirmed by twodimensional $\left({ }^{1} \mathrm{H},{ }^{1} \mathrm{H}\right.$-COSY, ${ }^{1} \mathrm{H},{ }^{1} \mathrm{H}$-NOESY, ${ }^{1} \mathrm{H},{ }^{13} \mathrm{C}$-HSQC, ${ }^{1} \mathrm{H},{ }^{13} \mathrm{C}$ $\mathrm{HMBC}$ ) experiments. The following abbreviations have been used for multiplicities: s, singlet; $d$, doublet; $t$, triplet; $q$, quartet; $m$, multiplet; $\mathrm{dd}$, doublet of doublets.

IR Spectroscopy. IR spectra were recorded using a Bruker ALPHA spectrometer equipped with a diamond ATR unit. The following abbreviations were used for the intensities and characteristics of important IR absorption bands: vs, very strong; s, strong; m, medium; w, weak; br, broad.

Electrochemistry and UV-Vis-NIR Spectroelectrochemistry. UV-vis-NIR absorption spectra were recorded on a J\&M TIDAS spectrophotometer. Cyclic voltammetry was carried out in 0.1 $\mathrm{M} \mathrm{Bu}_{4} \mathrm{NPF}_{6} / \mathrm{THF}$ solutions using a three-electrode configuration (Pt working, Pt-wire counter, and $\mathrm{Ag}$ quasi-reference electrodes) and was performed on a Metrohm Autolab potentiostat. THF was distilled from $\mathrm{Na} / \mathrm{K}$ amalgam and degassed directly before use in the electrochemistry.

X-ray Crystallography. Single-crystal X-ray diffraction data were recorded on an Agilent Technologies SuperNova diffractometer with $\mathrm{Cu} \mathrm{K} \alpha$ radiation $(\lambda=1.54184 \AA)$. Crystals were selected under mineral oil, mounted on MicroMount loops, and quench-cooled using an Oxford Cryo-system open flow $\mathrm{N}_{2}$ cooling device. Either semiempirical multiscan absorption corrections ${ }^{45}$ or analytical corrections ${ }^{46}$ were applied to the data. Using Olex $2,{ }^{47}$ the structures were solved with the SHELXT ${ }^{48}$ structure solution program using intrinsic phasing and refined with the SHELXL ${ }^{49}$ refinement package using least-squares refinements on $F^{2}{ }^{50}$ The hydrogen atoms were located in idealized positions and refined isotropically with a riding model. Crystallographic data for the structures in this paper have been deposited with the Cambridge Crystallographic Data Centre, CCDC, 12 Union Road, Cambridge CB21EZ, UK. Copies of the data can be 
obtained free of charge on quoting the depository numbers: 2056040 (for 1), 2056041 (for 2), 2056042 (for 3), 2056043 (for 4), 2056044 (for 5), 2056046 (for 6), and 2056045 (for 7).

Starting Materials. The chelating bidentate isonitrile ligands bis(2-isocyanophenyl) phenylphosphonate (BINC) ${ }^{6}$ and 2,2"-diisocyano-3,5,3", $5^{\prime \prime}$-tetramethyl-1,1 $1^{\prime}: 3^{\prime}, 1^{\prime \prime}$-terphenyl $\left(\mathrm{CNAr}_{3} \mathrm{NC}\right)^{7}$ and $[\mathrm{Cp} * \mathrm{FeCl}(\mathrm{tmeda})]^{33}$ were prepared according to reported procedures.

\section{Synthesis of trans-[FeBr $\left.2(\mathrm{BINC})_{2}\right](1)$}

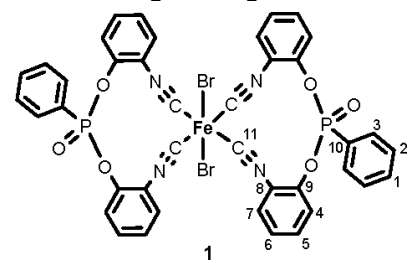

A solution of BINC $(0.350 \mathrm{~g}, 0.970 \mathrm{mmol})$ in THF $(10 \mathrm{~mL})$ was added to a solution of $\mathrm{FeBr}_{2}(0.100 \mathrm{~g}, 0.460 \mathrm{mmol})$ in THF $(60 \mathrm{~mL})$ at ambient temperature. The brownish orange reaction mixture turned into a grayish suspension after $30 \mathrm{~min}$. After the mixture was stirred overnight, product 1 could be isolated as a blue solid after decanting off the supernatant solution, washing with THF $(3 \times 10$ $\mathrm{mL}$ ), and drying in vacuo. Recrystallization by slow diffusion of $n$ hexane into a DCM solution resulted in blue crystals of 1 . Yield: 154 $\mathrm{mg}, 33 \%$ (the calculated yield assumes the presence of $8 \% \mathrm{FeBr}_{2}$ in the sample, vide infra). Anal. Calcd for $\mathrm{C}_{40} \mathrm{H}_{26} \mathrm{Br}_{2} \mathrm{FeN}_{4} \mathrm{O}_{6} \mathrm{P}_{2}(\mathrm{MW}=$ 936.27 g/mol): C, 51.31; H 2.80; N, 5.98. Found: C, 50.27; H, 2.87; $\mathrm{N}$, 5.77. Elemental analyses consistently gave low carbon and nitrogen, which indicated the presence of a persistent impurity. The impurity could not be removed by extraction or crystallization. We presume the impurity to be unreacted $\mathrm{FeBr}_{2}$. A calculated $\mathrm{C}, \mathrm{H}, \mathrm{N}$ analysis for $1 \cdot 0.08 \mathrm{FeBr}_{2}(\mathrm{C}, 50.39 ; \mathrm{H}, 2.75 ; \mathrm{N}, 5.88)$ fits well to the values found (C, 50.27; $\mathrm{H}, 2.87 ; \mathrm{N}, 5.77) .{ }^{1} \mathrm{H}$ NMR $(400.13 \mathrm{MHz}$, $\left.300 \mathrm{~K}, \mathrm{CD}_{2} \mathrm{Cl}_{2}\right): \delta(\mathrm{ppm}) 8.31-8.37\left(\mathrm{~m}, 4 \mathrm{H}, \mathrm{H}_{2}\right), 7.71\left(\mathrm{~d},{ }^{3} \mathrm{~J}_{\mathrm{HH}}=8.5\right.$ $\left.\mathrm{Hz}, 4 \mathrm{H}, \mathrm{H}_{4}\right), 7.65\left(\mathrm{~d},{ }^{3} \mathrm{~J}_{\mathrm{HH}}=7.9 \mathrm{~Hz}, 4 \mathrm{H}, \mathrm{H}_{7}\right), 7.6\left(\mathrm{dt},{ }^{3} J_{\mathrm{HH}}=1.4 \mathrm{~Hz}\right.$, $\left.{ }^{3} J_{\mathrm{HH}}=7.5 \mathrm{~Hz}, 2 \mathrm{H}, \mathrm{H}_{1}\right), 7.46-7.50\left(\mathrm{~m}, 2 \mathrm{H}, \mathrm{H}_{3}\right), 7.40\left(\mathrm{dt},{ }^{3} \mathrm{~J}_{\mathrm{HH}}=1.6\right.$ $\left.\mathrm{Hz},{ }^{3} \mathrm{~J}_{\mathrm{HH}}=7.7 \mathrm{~Hz}, 4 \mathrm{H}, \mathrm{H}_{5}\right), 7.28\left(\mathrm{t},{ }^{3} \mathrm{~J}_{\mathrm{HH}}=7.7 \mathrm{~Hz}, 4 \mathrm{H}, \mathrm{H}_{6}\right) .{ }^{13} \mathrm{C}\left\{{ }^{1} \mathrm{H}\right\}-$ NMR (100.61 MHz, $\left.300 \mathrm{~K}, \mathrm{CD}_{2} \mathrm{Cl}_{2}\right) \delta(\mathrm{ppm}) 147.4(\mathrm{~d}, J=7.0 \mathrm{~Hz}$, $\left.\mathrm{C}_{9}\right), 134.6\left(\mathrm{~d}, J=2.6 \mathrm{~Hz}, \mathrm{C}_{1}\right), 133.9\left(\mathrm{~d}, J=11.5 \mathrm{~Hz}, \mathrm{C}_{2}\right), 130.8(\mathrm{~s}$, $\left.\mathrm{C}_{5}\right), 129.4\left(\mathrm{~d}, J=16.4 \mathrm{~Hz}, \mathrm{C}_{3}\right), 127.6\left(\mathrm{~s}, \mathrm{C}_{7}\right), 126.1\left(\mathrm{~s}, \mathrm{C}_{6}\right), 123.8(\mathrm{~d}$, $\left.J=190 \mathrm{~Hz}, \mathrm{C}_{10}\right), 121.9\left(\mathrm{~d}, J=2.7 \mathrm{~Hz}, \mathrm{C}_{4}\right), 121.2\left(\mathrm{~d}, J=5.1 \mathrm{~Hz}, \mathrm{C}_{8}\right)$, $\left(\mathrm{C}_{11} \equiv \mathrm{N}\right)$ signals were not detected. ${ }^{31} \mathrm{P}\left\{{ }^{1} \mathrm{H}\right\}$-NMR $(161.98 \mathrm{MHz}$, $\left.300 \mathrm{~K}, \mathrm{CD}_{2} \mathrm{Cl}_{2}\right): \delta(\mathrm{ppm}) 15.5(\mathrm{~s}, 2 \mathrm{P})$. IR: $\nu\left(\mathrm{cm}^{-1}\right) 2122(\nu[\mathrm{C} \equiv \mathrm{N}]$, vs), $1585(\mathrm{w}), 1486(\mathrm{~s}), 1486(\mathrm{~m}), 1439(\mathrm{~m}), 1288(\mathrm{~m}), 1239(\mathrm{~m})$, $1130(\mathrm{~s}), 1100(\mathrm{~s}), 1031$ (m), 916 (br s), 799 (s), 755 (s), 713 (m), $596(\mathrm{~s}), 563$ (s), 531 (vs).

Synthesis of $\left[\mathrm{Fe}_{3}(\mathrm{BINC})_{6}\right](2)$.

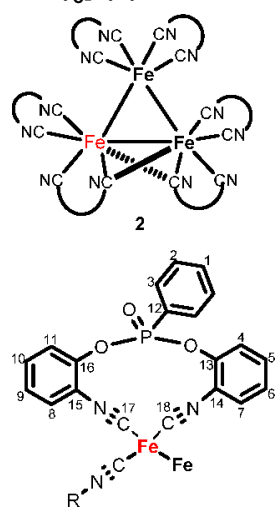

$\mathrm{KC}_{8}$ (coarse, $144 \mathrm{mg}, 1.068 \mathrm{mmol}$ ) was added in portions to a suspension of $1(500 \mathrm{mg}, 0.534 \mathrm{mmol})$ in THF $(30 \mathrm{~mL})$ at $-80{ }^{\circ} \mathrm{C}$. After the mixture was stirred overnight and warmed to room temperature, a brownish yellow solution was formed. The solution was filtered, concentrated in vacuo (ca. $15 \mathrm{~mL}$ ), and layered with $n$ hexane $(20 \mathrm{~mL})$. Product 2 could be isolated as brown crystals after decanting off the supernatant solution and drying under vacuum.
Yield: $107 \mathrm{mg}, 26 \%$. Anal. Calcd for $\mathrm{C}_{120} \mathrm{H}_{78} \mathrm{Fe}_{3} \mathrm{O}_{18} \mathrm{~N}_{12} \mathrm{P}_{6}(\mathrm{MW}=$ $2329.39 \mathrm{~g} / \mathrm{mol})$ : C, 61.88; H, 3.38; N, 7.22. Found: C, 61.47; H, 3.42; N, 6.95. ${ }^{1} \mathrm{H}$ NMR $\left(400,13 \mathrm{MHz}, 300 \mathrm{~K}, \mathrm{THF}-d_{8}\right): \delta$ (ppm) 8.50 $\left(\mathrm{dd},{ }^{4} J_{\mathrm{HH}}=1.1 \mathrm{~Hz},{ }^{3} J_{\mathrm{HH}}=8.1 \mathrm{~Hz}, 1 \mathrm{H}, \mathrm{H}_{7}\right), 8.29\left(\mathrm{~m}, 2 \mathrm{H}, \mathrm{H}_{2}\right), 7.56$ $\left(\mathrm{d},{ }^{3} J_{\mathrm{HH}}=8.1 \mathrm{~Hz}, 1 \mathrm{H}, \mathrm{H}_{4}\right), 7.14-7.16\left(\mathrm{~m}, 1 \mathrm{H}, \mathrm{H}_{5}\right), 7.13\left(\mathrm{~d},{ }^{3} \mathrm{~J}_{\mathrm{HH}}=\right.$ $\left.8.0 \mathrm{~Hz}, 1 \mathrm{H}, \mathrm{H}_{11}\right), 6.94\left(\mathrm{t},{ }^{3} J_{\mathrm{HH}}=8.1 \mathrm{~Hz}, 1 \mathrm{H}, \mathrm{H}_{6}\right), 6.83\left(\mathrm{t},{ }^{3} J_{\mathrm{HH}}=7.4\right.$ $\left.\mathrm{Hz}, 1 \mathrm{H}, \mathrm{H}_{1}\right), 6.68-6.75\left(\mathrm{~m}, 2 \mathrm{H}, \mathrm{H}_{3}\right), 6.68-6.75\left(\mathrm{~m}, 1 \mathrm{H}, \mathrm{H}_{10}\right), 6.53-$ $6.57\left(\mathrm{dt},{ }^{3} J_{\mathrm{HH}}=1.0 \mathrm{~Hz},{ }^{3} J_{\mathrm{HH}}=7.8 \mathrm{~Hz}, 1 \mathrm{H}, \mathrm{H}_{9}\right), 5.48\left(\mathrm{~d},{ }^{3} J_{\mathrm{HH}}=7.8\right.$ $\left.\mathrm{Hz}, 1 \mathrm{H}, \mathrm{H}_{8}\right) .{ }^{13} \mathrm{C}\left\{{ }^{1} \mathrm{H}\right\} \mathrm{NMR}\left(100.61 \mathrm{MHz}, 300 \mathrm{~K}, \mathrm{THF}-d_{8}\right): \delta(\mathrm{ppm})$ $218.7\left(\mathrm{~s}, \mathrm{C}_{18}\right), 188.1\left(\mathrm{~s}, \mathrm{C}_{17}\right), 146.4\left(\mathrm{~d}, J=5.0 \mathrm{~Hz}, \mathrm{C}_{16}\right), 144.9$ (d, $J=$ $10.1 \mathrm{~Hz}, \mathrm{C}_{13}$ ), 134.0 (d, $J=10.7 \mathrm{~Hz}, \mathrm{C}_{2}$ ), 133.9 (d, $J=2.8 \mathrm{~Hz}, \mathrm{C}_{1}$ ), 130.7 (d, $J=4.2 \mathrm{~Hz}, \mathrm{C}_{14}$ ), 128.9 (d, $J=15.7 \mathrm{~Hz}, \mathrm{C}_{3}$ ), $127.4\left(\mathrm{~s}, \mathrm{C}_{7}\right.$ ), 126.9 (d, $\mathrm{C}_{5}$ ), 126.7 (s, $\left.\mathrm{C}_{6}\right), 126.6\left(\mathrm{~s}, \mathrm{C}_{10}\right), 126.5$ (d, J = $188.9 \mathrm{~Hz}$, $\mathrm{C}_{12}$ ), $125.2\left(\mathrm{~s}, \mathrm{C}_{9}\right), 124.9\left(\mathrm{~s}, \mathrm{C}_{8}\right), 123.4\left(\mathrm{~d}, J=2.1 \mathrm{~Hz}, \mathrm{C}_{4}\right), 123.3(\mathrm{~d}$, $\left.J=7.2 \mathrm{~Hz}, \mathrm{C}_{15}\right), 120.2\left(\mathrm{~s}, \mathrm{C}_{11}\right) .{ }^{31} \mathrm{P}\left\{{ }^{1} \mathrm{H}\right\} \operatorname{NMR}(161.98 \mathrm{MHz}, 300$, THF $\left.-d_{8}\right): \delta(\mathrm{ppm}) 13.2(\mathrm{~s})$. IR: $\nu\left(\mathrm{cm}^{-1}\right) 2035(\nu[\mathrm{C} \equiv \mathrm{N}]$, br m), $1643(\mathrm{~m}), 1581(\mathrm{~s}), 1485(\mathrm{~s}), 1451(\mathrm{~m}), 1440(\mathrm{~m}), 1282(\mathrm{~m}), 1265$ (s), 1247 (s), 1200 (w), 1130 (s), 1101 (s), 927 (vs), 809 (s), 753 (vs). 516 (s).

\section{Synthesis of [Cp*FeCl(BINC)] (3).}

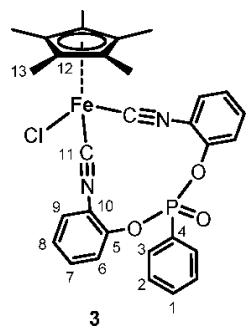

A solution of BINC (420 mg, $1.17 \mathrm{mmol})$ in THF $(5 \mathrm{~mL})$ was added to a yellow solution of $\left[\mathrm{Cp}^{*} \mathrm{FeCl}(\mathrm{tmeda})\right]^{33}(400 \mathrm{mg}, 1.17 \mathrm{mmol})$ in THF $(15 \mathrm{~mL})$. An immediate color change to dark red occurred. After the reaction mixture was stirred overnight, a red-brown suspension was formed. After the solvent was removed under reduced pressure, the brown solid was dried in vacuo. Recrystallization by slow diffusion of $n$-hexane into a DCM solution resulted in red-black crystals of 3. Yield: $560 \mathrm{mg}, 82 \%$. Anal. Calcd for $\mathrm{C}_{30} \mathrm{H}_{28} \mathrm{ClFeN}_{2} \mathrm{O}_{3} \mathrm{P}$ $(\mathrm{MW}=586.83 \mathrm{~g} / \mathrm{mol}): \mathrm{C}, 61.40 ; \mathrm{H}, 4.81 ; \mathrm{N}, 4.77$. Found: $\mathrm{C}, 60.78$; $\mathrm{H}, 4.81 ; \mathrm{N}, 4.70$. The elemental analysis consistently indicates the presence of persistent impurities in samples of $\mathbf{3}$ prepared in the above manner. The unknown impurities could not be removed by washing or recrystallization of compound $3 .{ }^{1} \mathrm{H}$ NMR $(400.13 \mathrm{MHz}, 300 \mathrm{~K}$, $\left.\mathrm{CDCl}_{3}\right): \delta(\mathrm{ppm}) 8.17-8.11\left(\mathrm{~m}, 2 \mathrm{H}, \mathrm{H}_{2}\right), 8.12\left(\mathrm{~d},{ }^{3} J_{\mathrm{HH}}=7.4 \mathrm{~Hz}, 1 \mathrm{H}\right.$, $\mathrm{H}_{3}$ or $\left.\mathrm{H}_{3^{\prime}}\right), 7.56\left(\mathrm{~d},{ }^{3} \mathrm{~J}_{\mathrm{HH}}=8.1 \mathrm{~Hz}, 2 \mathrm{H}, \mathrm{H}_{6}\right), 7.48-7.42\left(\mathrm{~m}, 3 \mathrm{H}, \mathrm{H}_{1} /\right.$ $\left.\mathrm{H}_{3}\right), 7.27\left(\mathrm{~d},{ }^{3} J_{\mathrm{HH}}=7.6 \mathrm{~Hz}, 2 \mathrm{H}, \mathrm{H}_{9}\right), 7.15\left(\mathrm{t},{ }^{3} \mathrm{~J}_{\mathrm{HH}}=7.6 \mathrm{~Hz}, 2 \mathrm{H}, \mathrm{H}_{7}\right)$, $7.08\left(\mathrm{t},{ }^{3} \mathrm{~J}_{\mathrm{HH}}=7.6 \mathrm{~Hz}, 2 \mathrm{H}, \mathrm{H}_{8}\right), 1.75\left(\mathrm{~s}, 15 \mathrm{H}, \mathrm{H}-\mathrm{Cp}^{*}\right) .{ }^{13} \mathrm{C}\left\{{ }^{1} \mathrm{H}\right\} \mathrm{NMR}$ $\left(100.61 \mathrm{MHz}, 300 \mathrm{~K}, \mathrm{CDCl}_{3}\right): \delta(\mathrm{ppm}) 188.7\left(\mathrm{~s}, \mathrm{C}_{11}\right), 146.1(\mathrm{~d}, J=$ $\left.6.6 \mathrm{~Hz}, \mathrm{C}_{5}\right), 133.9$ (d, J = 3.2 Hz, C 1 ), 133.5 (d, J = 11.5 Hz, C $)_{2}$, 128.9 (d, $\left.J=16.5 \mathrm{~Hz}, \mathrm{C}_{3}\right), 127.7\left(\mathrm{~d}, J=1.1 \mathrm{~Hz}, \mathrm{C}_{7}\right), 125.6\left(\mathrm{~s}, \mathrm{C}_{9}\right)$, $125.4\left(\mathrm{~d}, J=1.0 \mathrm{~Hz}, \mathrm{C}_{8}\right), 123.4\left(\mathrm{~d}, J=189.9 \mathrm{~Hz}, \mathrm{C}_{4}\right), 123.2(\mathrm{~d}, J=$ $6.2 \mathrm{~Hz}, \mathrm{C}_{10}$ ), 121.4 (d, J = 2.8 Hz, C $\left.\mathrm{C}_{6}\right), 93.1\left(\mathrm{~s}, \mathrm{C}_{12}\right), 9.9\left(\mathrm{~s}, \mathrm{C}_{13}\right)$. ${ }^{31} \mathrm{P}\left\{{ }^{1} \mathrm{H}\right\} \operatorname{NMR}\left(161.98 \mathrm{MHz}, 300 \mathrm{~K}, \mathrm{CDCl}_{3}\right): \delta(\mathrm{ppm}) 15.2(\mathrm{~s}, 1 \mathrm{P})$. IR: $\nu\left(\mathrm{cm}^{-1}\right) 2908(\mathrm{w}), 2084(\nu[\mathrm{C} \equiv \mathrm{N}], \mathrm{s}), 2023(\nu[\mathrm{C} \equiv \mathrm{N}], \mathrm{s})$, $2011(\nu[\mathrm{C} \equiv \mathrm{N}], \mathrm{s}), 1489(\mathrm{~s}), 1439(\mathrm{~m}), 1265$ (m), $1244(\mathrm{~m}), 1102$ (s), 944 (vs), 923 (vs), 763 (vs), 573 (s). 
Synthesis of $[\mathrm{Cp} * \mathrm{Fe}(\mathrm{BINC})]_{2}$ (4).

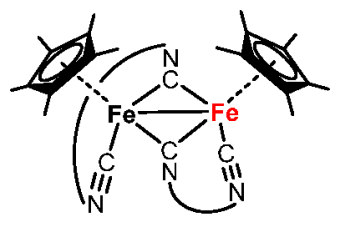

4

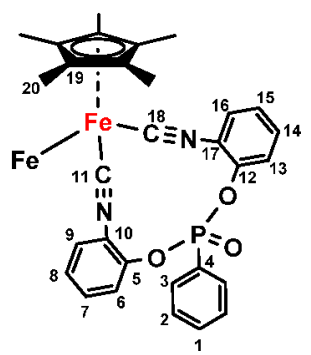

$\mathrm{KC}_{8}$ (coarse, $138 \mathrm{mg}, 1.023 \mathrm{mmol}$ ) was added to a red suspension of $3(600 \mathrm{mg}, 1.023 \mathrm{mmol})$ in THF $(30 \mathrm{~mL})$ at $-80{ }^{\circ} \mathrm{C}$. The green reaction solution obtained was stirred and warmed to room temperature overnight. After filtration and concentration under vacuum the green solution was layered with $n$-hexane. After the supernatant solution was decanted off and dried under vacuum, $\mathbf{4}$ was isolated as green crystals. Yield: $100 \mathrm{mg}, 18 \%$. Anal. Calcd for $\mathrm{C}_{60} \mathrm{H}_{56} \mathrm{Fe}_{2} \mathrm{~N}_{4} \mathrm{O}_{6} \mathrm{P}_{2}(\mathrm{MW}=1102.77 \mathrm{~g} / \mathrm{mol}): \mathrm{C}, 65.35 ; \mathrm{H}, 5.12 ; \mathrm{N}$, 5.08. Found: C, 65.06; H, 5.33; N, 4.84. ${ }^{1} \mathrm{H}$ NMR $(400.13 \mathrm{MHz}, 300$ $\mathrm{K}$, THF- $\left.d_{8}\right): \delta(\mathrm{ppm}) 8.14-8.09\left(\mathrm{~m}, 4 \mathrm{H}, \mathrm{H}_{2}, c i s\right), 8.10-8.05(\mathrm{~m}$, $1.3 \mathrm{H}, \mathrm{H}_{2}$, trans), $7.77-7.72\left(\mathrm{~m}, 1.3 \mathrm{H}, \mathrm{H}_{2}\right.$, trans $), 7.66-7.63(\mathrm{~m}$, $2.3 \mathrm{H}, \mathrm{H}_{1}$, cis (overlapping with trans)), 7.60-7.55 (m, $\left.4.7 \mathrm{H}, \mathrm{H}_{3}, c i s\right)$, $7.53-7.48\left(\mathrm{~m}, 1.4 \mathrm{H}, \mathrm{H}_{3}\right.$, trans $), 7.44\left(\mathrm{~d},{ }^{3} \mathrm{~J}=7.6 \mathrm{~Hz}, 0.8 \mathrm{H}, \mathrm{H}_{\mathrm{Ar}}\right.$, trans), $7.40-7.38\left(\mathrm{~m}, 2.8 \mathrm{H}, \mathrm{H}_{6}\right.$, cis $), 7.34-7.32\left(\mathrm{~m}, 2.8 \mathrm{H}, \mathrm{H}_{9}\right.$, cis (overlapping with trans)), 7.29-7.22 (m, 2.6 $\mathrm{H}, \mathrm{H}_{\mathrm{Ar}}$, trans), 7.11-7.08 (m, $1 \mathrm{H}, \mathrm{H}_{\mathrm{Ar}}$, trans), $7.05-7.02\left(\mathrm{t},{ }^{3} \mathrm{~J}=7.6 \mathrm{~Hz}, 2.3 \mathrm{H}, \mathrm{H}_{8}\right.$, cis $), 7.01-$ $6.95(\mathrm{~m}, 2.0 \mathrm{H}$, trans $), 6.88\left(\mathrm{t},{ }^{3} \mathrm{~J}=7.6 \mathrm{~Hz}, 1 \mathrm{H}, \mathrm{H}_{\mathrm{Ar}}\right.$, trans $), 6.70\left(\mathrm{t},{ }^{3} \mathrm{~J}\right.$ $\left.=7.6 \mathrm{~Hz}, 2.0 \mathrm{H}, \mathrm{H}_{14}, c i s\right), 6.64\left(\mathrm{t},{ }^{3} \mathrm{~J}=7.6 \mathrm{~Hz}, 2.8 \mathrm{H}, \mathrm{H}_{7}, c i s\right), 6.54\left(\mathrm{t},{ }^{3} \mathrm{~J}\right.$ $=7.6 \mathrm{~Hz}, 1 \mathrm{H}, \mathrm{H}_{\mathrm{Ar}}$, trans $), 6.48-6.44\left(\mathrm{~m}, 1.3 \mathrm{H}, \mathrm{H}_{\mathrm{Ar}}\right.$, trans $), 6.45-6.37$ ( $\mathrm{m}, 4 \mathrm{H}, \mathrm{H}_{13}$ and $\mathrm{H}_{15}$, cis (overlapping with trans)), $6.32\left(\mathrm{t},{ }^{3} \mathrm{~J}=7.6\right.$ $\mathrm{Hz}, 0.8 \mathrm{H}, \mathrm{H}_{\mathrm{Ar}}$, trans $), 6.27\left(\mathrm{~d},{ }^{3} \mathrm{~J}=7.6 \mathrm{~Hz}, 0.6 \mathrm{H}, \mathrm{H}_{16}\right.$, trans $), 6.18(\mathrm{~d}$, $\left.{ }^{3} \mathrm{~J}=7.6 \mathrm{~Hz}, 2 \mathrm{H}, \mathrm{H}_{16}, c i s\right), 6.14\left(\mathrm{~d},{ }^{3} \mathrm{~J}=7.6 \mathrm{~Hz}, 0.6 \mathrm{H}, \mathrm{H}_{16}\right.$, trans $), 1.87$ (s, $8.4 \mathrm{H}, \mathrm{H}_{20}$, trans-Cp*), $1.74\left(\mathrm{~s}, 30 \mathrm{H}, \mathrm{H}_{20}\right.$, cis-Cp* $\left.\mathrm{Cp}^{*}\right), 1.63(\mathrm{~s}, 8.2 \mathrm{H}$, $\mathrm{H}_{20}$, trans-Cp*). ${ }^{13} \mathrm{C}\left\{{ }^{1} \mathrm{H}\right\}$ NMR $\left(100.61 \mathrm{MHz}, 300 \mathrm{~K}\right.$, THF- $\left.d_{8}\right): \delta$ (ppm) 265.1 (s, $\left.\mathrm{C}_{11}, c i s\right), 262.6$ ( $\mathrm{s}, \mathrm{C}_{11}$, trans), 259.9 ( $\mathrm{s}, \mathrm{C}_{11}$, trans), $189.9\left(\mathrm{~s}, \mathrm{C}_{18}\right.$, trans), $183.7\left(\mathrm{~s}, \mathrm{C}_{18}\right.$, cis $), 182.7\left(\mathrm{~s}, \mathrm{C}_{18}\right.$, trans $), 143.9(\mathrm{~d}$, $\left.J=10.7 \mathrm{~Hz}, \mathrm{C}_{12}, c i s\right), 144.0\left(\mathrm{~d}, J=10.4 \mathrm{~Hz}, \mathrm{C}_{12}\right.$, trans $), 146.0\left(\mathrm{~m}, \mathrm{C}_{12}\right.$, trans), 138.9 (d, $\left.J=5.0 \mathrm{~Hz}, \mathrm{C}_{5}, c i s\right), 138.6\left(\mathrm{~d}, J=5.0 \mathrm{~Hz}, \mathrm{C}_{5}\right.$, trans), $138.3\left(\mathrm{~d}, J=5.0 \mathrm{~Hz}, \mathrm{C}_{5}\right.$, trans), $137.4\left(\mathrm{~d}, J=6.3 \mathrm{~Hz}, \mathrm{C}_{10}, c i s\right), 137.0$ (d, $J=4.5 \mathrm{~Hz}, \mathrm{C}_{10}$, trans), $137.8\left(\mathrm{~d}, J=6.0 \mathrm{~Hz}, \mathrm{C}_{10}\right.$, trans $), 133.0(\mathrm{~d}, J$ $=10.3 \mathrm{~Hz}, \mathrm{C}_{2}$, trans), $132.9\left(\mathrm{~d}, J=11.3 \mathrm{~Hz}, \mathrm{C}_{2}, c i s\right), 132.8(\mathrm{~d}, J=10.5$ $\mathrm{Hz}, \mathrm{C}_{2}$, trans), 132.6 ( $\mathrm{m}, \mathrm{C}_{1}$, cis), $128.2\left(\mathrm{~d}, J=15.8 \mathrm{~Hz}, \mathrm{C}_{3}, c i s\right), 127.9$ (d, $J=15.8 \mathrm{~Hz}, \mathrm{C}_{3}$, trans), $127.7\left(\mathrm{~d}, J=15.5 \mathrm{~Hz}, \mathrm{C}_{3}\right.$, trans), 127.6 (s, $\left.\mathrm{C}_{\mathrm{Ar}}\right), 126.7\left(\mathrm{~d}, J=1.7 \mathrm{~Hz}, \mathrm{C}_{16}\right), 125.7\left(\mathrm{~s}, \mathrm{C}_{\mathrm{Ar}}\right), 125.6(\mathrm{dd}, J=1.8 \mathrm{~Hz}$, $\left.J=6.3 \mathrm{~Hz}, \mathrm{C}_{\mathrm{Ar}}\right), 125.1\left(\mathrm{~d}, J=1.7 \mathrm{~Hz}, \mathrm{C}_{14}\right), 124.8\left(\mathrm{~s}, \mathrm{C}_{\mathrm{Ar}}\right), 124.6(\mathrm{~s}$, $\mathrm{C}_{\mathrm{Ar}}$ trans), $124.5\left(\mathrm{~s}, \mathrm{C}_{8}, c i s\right), 124.0\left(\mathrm{~d}, J=3.4 \mathrm{~Hz}, \mathrm{C}_{17}, c i s\right), 123.6(\mathrm{~d}, J$ $\left.=190 \mathrm{~Hz}, \mathrm{C}_{4}, c i s\right), 123.3\left(\mathrm{~d}, J=3.4 \mathrm{~Hz}, \mathrm{C}_{13}\right.$ and $\left.\mathrm{C}_{15}, c i s\right), 123.8(\mathrm{~d}, J=$ $3.4 \mathrm{~Hz}, \mathrm{C}_{\mathrm{Ar}}$ ), 122.8 (s, $\mathrm{C}_{9}$, trans), 122.7 (s, $\mathrm{C}_{9}, \mathrm{cis}$ ), 122.5 (s, $\mathrm{C}_{9}$, trans), 119.9 (d, $J=2.8 \mathrm{~Hz}, \mathrm{C}_{\mathrm{Ar}}$ ), $119.7\left(\mathrm{~s}, \mathrm{C}_{6}, c i s\right), 119.6(\mathrm{~d}, J=2.8$ $\left.\mathrm{Hz}, \mathrm{C}_{7}, c i s\right), 119.4\left(\mathrm{~s}, \mathrm{C}_{\mathrm{Ar}}\right), 118.9\left(\mathrm{~d}, J=1.4 \mathrm{~Hz}, \mathrm{C}_{\mathrm{Ar}}\right), 118.7(\mathrm{~d}, J=2.5$ $\mathrm{Hz}, \mathrm{C}_{\mathrm{Ar}}$ ), 96.7 (s, $\mathrm{C}_{19}$, trans), 96.3 (s, $\left.\mathrm{C}_{19}, \mathrm{cis}\right), 95.7$ (s, $\mathrm{C}_{19}$, trans), $10.8\left(\mathrm{~s}, \mathrm{C}_{20}\right.$, trans $), 10.0\left(\mathrm{~s}, \mathrm{C}_{20}\right.$, cis $), 9.3\left(\mathrm{~s}, \mathrm{C}_{20}\right.$, trans $) .{ }^{31} \mathrm{P}\left\{{ }^{1} \mathrm{H}\right\} \mathrm{NMR}$ $\left(161.98 \mathrm{MHz}, 300 \mathrm{~K}, \mathrm{THF}-d_{8}\right): \delta$ (ppm) 14.5 (s, 2P, cis), 14.3 (s, 0.6P, trans), 12.1 (s, 0.6P, trans). IR: $\nu\left(\mathrm{cm}^{-1}\right) 3057(\mathrm{w}), 2899(\mathrm{w})$, $2853(\mathrm{w}), 2053(\nu[\mathrm{C} \equiv \mathrm{N}]$, br s $), 2028(\nu[\mathrm{C} \equiv \mathrm{N}]$, br s $), 1656(\mathrm{~s})$, 1580 (s), 1478 (s), $1440(\mathrm{~m}), 1256$ (s), 1129 (s), 1098 (s), 924 (vs), 750 (vs), 645 (s), $580(\mathrm{~s}), 533(\mathrm{~s}), 501(\mathrm{~s})$.
Synthesis of $\left[\mathrm{FeBr}_{2}\left(\mathrm{CNAr}_{3} \mathrm{NC}\right)_{2}\right]$ (5).

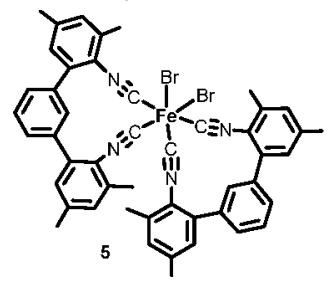

A solution of $\mathrm{CNAr}_{3} \mathrm{NC}(98.3 \mathrm{mg}, 0.292 \mathrm{mmol})$ in THF $(15 \mathrm{~mL})$ was added to a solution of $\mathrm{FeBr}_{2}(30 \mathrm{mg}, 0.139 \mathrm{mmol})$ in THF $(15 \mathrm{~mL})$. After it was stirred overnight, the orange suspension was filtered and the remaining orange residue was washed with THF $(2 \times 5 \mathrm{~mL})$ and dried in vacuo. Recrystallization by slow diffusion of $n$-hexane into a DCM solution resulted in orange crystals of 5 . Yield: $73.6 \mathrm{mg}, 55 \%$ (the calculated yield assumes the presence of $8 \% \mathrm{FeBr}_{2}$ in the sample, vide infra). Anal. Calcd for $\mathrm{C}_{48} \mathrm{H}_{40} \mathrm{Br}_{2} \mathrm{FeN}_{4}(\mathrm{MW}=888.53 \mathrm{~g} / \mathrm{mol}): \mathrm{C}$, 64.89; H, 4.54; N, 6.3. Found: C, 63.58; H, 4.80; N, 5.93. Elemental analyses consistently gave low carbon and nitrogen values, which indicated the presence of a persistent impurity. The impurity could not be removed by extraction or crystallization. We presume the impurity to be unreacted $\mathrm{FeBr}_{2}$. A calculated $\mathrm{C}, \mathrm{H}, \mathrm{N}$ analysis for 5 . $0.08 \mathrm{FeBr}_{2}(\mathrm{C}, 63.65 ; \mathrm{H}, 4.48 ; \mathrm{N}, 6.19)$ fits well to the values found (C, 63.58; H, 4.80; N, 5.93). ${ }^{1} \mathrm{H}$ NMR $(400,13 \mathrm{MHz}, 213 \mathrm{~K}$, $\left.\mathrm{CD}_{2} \mathrm{Cl}_{2}\right): \delta(\mathrm{ppm}) 8.08\left(\mathrm{ps} \mathrm{t}, 1 \mathrm{H}, \mathrm{H}_{\mathrm{Ar}}\right), 7.77\left(\mathrm{ps} \mathrm{t}, 1 \mathrm{H}, \mathrm{H}_{\mathrm{Ar}}\right), 7.66(\mathrm{t}$, $\left.{ }^{3} J_{\mathrm{HH}}=7.7 \mathrm{~Hz}, 1 \mathrm{H}, \mathrm{H}_{\mathrm{Ar}}\right), 7.63\left(\mathrm{t},{ }^{3} J_{\mathrm{HH}}=7.7 \mathrm{~Hz}, 1 \mathrm{H}, \mathrm{H}_{\mathrm{Ar}}\right), 7.50(\mathrm{~d}$, $\left.{ }^{3} J_{\mathrm{HH}}=7.8 \mathrm{~Hz}, 1 \mathrm{H}, \mathrm{H}_{\mathrm{Ar}}\right), 7.46\left(\mathrm{~d},{ }^{3} J_{\mathrm{HH}}=7.8 \mathrm{~Hz}, 1 \mathrm{H}, \mathrm{H}_{\mathrm{Ar}}\right), 7.42(\mathrm{~d}$, $\left.{ }^{3} J_{\mathrm{HH}}=7.8 \mathrm{~Hz}, 1 \mathrm{H}, \mathrm{H}_{\mathrm{Ar}}\right), 7.35\left(\mathrm{~d},{ }^{3} \mathrm{~J}_{\mathrm{HH}}=7.8 \mathrm{~Hz}, 1 \mathrm{H}, \mathrm{H}_{\mathrm{Ar}}\right), 7.18(\mathrm{~s}$, $\left.1 \mathrm{H}, \mathrm{H}_{\mathrm{Ar}}\right), 7.14\left(\mathrm{~s}, 1 \mathrm{H}, \mathrm{H}_{\mathrm{Ar}}\right), 7.12\left(\mathrm{~s}, 1 \mathrm{H}, \mathrm{H}_{\mathrm{Ar}}\right), 7.09$ (br. s, $\left.2 \mathrm{H}, \mathrm{H}_{\mathrm{Ar}}\right)$, $7.05\left(\mathrm{~s}, 1 \mathrm{H}, \mathrm{H}_{\mathrm{Ar}}\right), 6.94\left(\mathrm{~s}, 1 \mathrm{H}, \mathrm{H}_{\mathrm{Ar}}\right), 6.91\left(\mathrm{~s}, 1 \mathrm{H}, \mathrm{H}_{\mathrm{Ar}}\right), 2.64(\mathrm{~s}, 3 \mathrm{H}$, $\left.\mathrm{H}_{\text {Methyl }}\right), 2.55\left(\mathrm{~s}, 3 \mathrm{H}, \mathrm{H}_{\text {Methyl }}\right), 2.53\left(\mathrm{~s}, 3 \mathrm{H}, \mathrm{H}_{\text {Methyl }}\right), 2.37$ (s, 6H, $\mathrm{H}_{\text {Methyl }}$ ), $2.33\left(\mathrm{~s}, 3 \mathrm{H}, \mathrm{H}_{\text {Methyl }}\right), 2.26$ (s, 3H, $\left.\mathrm{H}_{\text {Methyl }}\right), 1.53(\mathrm{~s}, 3 \mathrm{H}$, $\left.\mathrm{H}_{\text {Methyl }}\right) .{ }^{13} \mathrm{C}\left\{{ }^{1} \mathrm{H}\right\}$ NMR $\left(100.61 \mathrm{MHz}, 213 \mathrm{~K}, \mathrm{CD}_{2} \mathrm{Cl}_{2}\right): \delta$ (ppm) $167.3\left(\mathrm{~s}, \mathrm{C}_{\mathrm{CN}}\right), 166.8\left(\mathrm{~s}, \mathrm{C}_{\mathrm{CN}}\right), 164.6\left(\mathrm{~s}, \mathrm{C}_{\mathrm{CN}}\right), 164.4\left(\mathrm{~s}, \mathrm{C}_{\mathrm{CN}}\right), 139.4$ $\left(\mathrm{s}, \mathrm{C}_{\mathrm{Ar}}\right), 138.9\left(\mathrm{~s}, \mathrm{C}_{\mathrm{Ar}}\right), 138.6\left(\mathrm{~s}, \mathrm{C}_{\mathrm{Ar}}\right), 138.3\left(\mathrm{~s}, \mathrm{C}_{\mathrm{Ar}}\right), 137.8\left(\mathrm{~s}, \mathrm{C}_{\mathrm{Ar}}\right)$, $137.7\left(\mathrm{~s}, \mathrm{C}_{\mathrm{Ar}}\right), 137.1\left(\mathrm{~s}, \mathrm{C}_{\mathrm{Ar}}\right), 137.1\left(\mathrm{~s}, \mathrm{C}_{\mathrm{Ar}}\right), 136.9\left(\mathrm{~s}, \mathrm{C}_{\mathrm{Ar}}\right), 136.8(\mathrm{~s}$, $\left.\mathrm{C}_{\mathrm{Ar}}\right), 136.5\left(\mathrm{~s}, \mathrm{C}_{\mathrm{Ar}}\right), 136.1\left(\mathrm{~s}, \mathrm{C}_{\mathrm{Ar}}\right), 135.4\left(\mathrm{~s}, \mathrm{C}_{\mathrm{Ar}}\right), 135.2\left(\mathrm{~s}, \mathrm{C}_{\mathrm{Ar}}\right)$, $130.1\left(\mathrm{~s}, \mathrm{C}_{\mathrm{Ar}}\right), 130.0\left(\mathrm{~s}, \mathrm{C}_{\mathrm{Ar}}\right), 129.9\left(\mathrm{~s}, \mathrm{C}_{\mathrm{Ar}}\right), 129.9\left(\mathrm{~s}, \mathrm{C}_{\mathrm{Ar}}\right), 129.6(\mathrm{~s}$, $\left.\mathrm{C}_{\mathrm{Ar}}\right), 129.1\left(\mathrm{~s}, \mathrm{C}_{\mathrm{Ar}}\right), 129.0\left(\mathrm{~s}, \mathrm{C}_{\mathrm{Ar}}\right), 128.9\left(\mathrm{~s}, \mathrm{C}_{\mathrm{Ar}}\right), 128.9\left(\mathrm{~s}, \mathrm{C}_{\mathrm{Ar}}\right)$, $128.8\left(\mathrm{~s}, \mathrm{C}_{\mathrm{Ar}}\right), 128.6\left(\mathrm{~s}, \mathrm{C}_{\mathrm{Ar}}\right), 128.5\left(\mathrm{~s}, \mathrm{C}_{\mathrm{Ar}}\right), 128.5\left(\mathrm{~s}, \mathrm{C}_{\mathrm{Ar}}\right), 123.1(\mathrm{~s}$, $\left.\mathrm{C}_{\mathrm{Ar}}\right), 122.8\left(\mathrm{~s}, \mathrm{C}_{\mathrm{Ar}}\right), 122.2\left(\mathrm{~s}, \mathrm{C}_{\mathrm{Ar}}\right), 122.2\left(\mathrm{~s}, \mathrm{C}_{\mathrm{Ar}}\right), 21.1\left(\mathrm{~s}, \mathrm{C}_{\text {Methyl }}\right)$, 21.0 (s, $\mathrm{C}_{\text {Methyl }}$ ), 20.9 (s, $\left.\mathrm{C}_{\text {Methyl }}\right), 18.7$ (s, $\mathrm{C}_{\text {Methyl }}$ ), 18.7 (s, $\mathrm{C}_{\text {Methyl }}$ ), $18.6\left(\mathrm{~s}, \mathrm{C}_{\text {Methyl }}\right), 18.0\left(\mathrm{~s}, \mathrm{C}_{\text {Methyl }}\right)$. Characterization by NMR spectroscopy at $300 \mathrm{~K}$ showed broadened signals in the ${ }^{1} \mathrm{H}$ NMR spectra. Variable-temperature NMR confirmed the assumption of a cis/trans isomer mixture. The NMR characterization of compound 5 at $213 \mathrm{~K}\left(-60{ }^{\circ} \mathrm{C}\right)$ identified a $1: 1$ isomeric mixture. IR: $\nu\left(\mathrm{cm}^{-1}\right)$ $2158(\mathrm{w}), 2144$ ( $\nu[\mathrm{C} \equiv \mathrm{N}]$, vs), $2126(\nu[\mathrm{C} \equiv \mathrm{N}], \mathrm{vs}), 1594(\mathrm{w}), 1462$ (m), $860(\mathrm{~m}), 805(\mathrm{~s}), 733(\mathrm{~m}), 705(\mathrm{~s}), 607(\mathrm{~m}), 567(\mathrm{~m})$.

Synthesis of $\left[\mathrm{Fe}\left(\mathrm{CNAr}_{3} \mathrm{NC}\right)_{2}\right]_{2}(6)$.

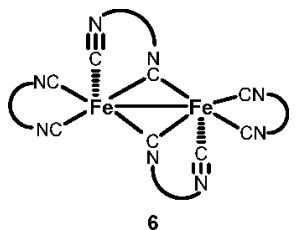

$\mathrm{KC}_{8}$ (coarse, $30.4 \mathrm{mg}, 0.225 \mathrm{mmol}$ ) was added in portions to a suspension of $5(100.0 \mathrm{mg}, 0.113 \mathrm{mmol})$ in THF $(15 \mathrm{~mL})$ at $-80{ }^{\circ} \mathrm{C}$. After $30 \mathrm{~min}$ a dark orange-red reaction solution was formed. The solution was stirred overnight and warmed to room temperature. The dark red reaction mixture was filtered and concentrated in vacuo (ca. 5 $\mathrm{mL}$ ), and 6 was crystallized by slow diffusion of $n$-hexane into a THF solution. Compound 6 was isolated as red-brown crystals. Yield: 10 mg, $12 \%$. Anal. Calcd for $\mathrm{C}_{96} \mathrm{H}_{80} \mathrm{Fe}_{2} \mathrm{~N}_{8}(\mathrm{Mw}=1457.44 \mathrm{~g} / \mathrm{mol}): \mathrm{C}$, 79.12; H, 5.53; N, 7.69. Found: C, 79.27; H, 5.89; N, 6.92. ${ }^{1} \mathrm{H}$ NMR $\left(400.13 \mathrm{MHz}, 300 \mathrm{~K}, \mathrm{THF}-d_{8}\right): \delta(\mathrm{ppm}) 8.53\left(\mathrm{~s}, 1 \mathrm{H}, \mathrm{H}_{\mathrm{Ar}}\right), 8.13(\mathrm{~s}$, $\left.1 \mathrm{H}, \mathrm{H}_{\mathrm{Ar}}\right), 8.10\left(\mathrm{~s}, 1 \mathrm{H}, \mathrm{H}_{\mathrm{Ar}}\right), 7.66\left(\mathrm{~s}, 1 \mathrm{H}, \mathrm{H}_{\mathrm{Ar}}\right), 7.49\left(\mathrm{~s}, 1 \mathrm{H}, \mathrm{H}_{\mathrm{Ar}}\right), 7.48$ $\left(\mathrm{t},{ }^{3} \mathrm{~J}=7.7 \mathrm{~Hz} 1 \mathrm{H}, \mathrm{H}_{\mathrm{Ar}}\right), 7.39\left(\mathrm{t},{ }^{3} \mathrm{~J}=7.4 \mathrm{~Hz} 1 \mathrm{H}, \mathrm{H}_{\mathrm{Ar}}\right), 7.35(\mathrm{~m}, 1 \mathrm{H}$, 
$\left.\mathrm{H}_{\mathrm{Ar}}\right), 7.32\left(\mathrm{~m}, 1 \mathrm{H}, \mathrm{H}_{\mathrm{Ar}}\right), 7.26\left(\mathrm{t},{ }^{3} J=7.6 \mathrm{~Hz} 1 \mathrm{H}, \mathrm{H}_{\mathrm{Ar}}\right), 7.15\left(\mathrm{~d},{ }^{3} J=\right.$ $\left.8.0 \mathrm{~Hz}, 1 \mathrm{H}, \mathrm{H}_{\mathrm{Ar}}\right), 7.10\left(\mathrm{~d},{ }^{3} \mathrm{~J}=8.0 \mathrm{~Hz}, 1 \mathrm{H}, \mathrm{H}_{\mathrm{Ar}}\right), 7.05\left(\mathrm{~m}, 3 \mathrm{H}, \mathrm{H}_{\mathrm{Ar}}\right)$, $7.00\left(\mathrm{~m}, 2 \mathrm{H}, \mathrm{H}_{\mathrm{Ar}}\right), 6.97\left(\mathrm{~m}, 3 \mathrm{H}, \mathrm{H}_{\mathrm{Ar}}\right), 6.89\left(\mathrm{~m}, 3 \mathrm{H}, \mathrm{H}_{\mathrm{Ar}}\right), 6.73(\mathrm{~m}$, $\left.2 \mathrm{H}, \mathrm{H}_{\mathrm{Ar}}\right), 6.67\left(\mathrm{~m}, 2 \mathrm{H}, \mathrm{H}_{\mathrm{Ar}}\right), 6.62\left(\mathrm{~m}, 2 \mathrm{H}, \mathrm{H}_{\mathrm{Ar}}\right), 6.59\left(\mathrm{~m}, 2 \mathrm{H}, \mathrm{H}_{\mathrm{Ar}}\right)$, $6.55\left(\mathrm{~m}, 1 \mathrm{H}, \mathrm{H}_{\mathrm{Ar}}\right), 6.44\left(\mathrm{~d},{ }^{3} \mathrm{~J}=7.6 \mathrm{~Hz}, 1 \mathrm{H}, \mathrm{H}_{\mathrm{Ar}}\right), 6.40\left(\mathrm{dd},{ }^{3} \mathrm{~J}=7.8\right.$ $\left.\mathrm{Hz},{ }^{3} \mathrm{~J}=1.5 \mathrm{~Hz}, 1 \mathrm{H}, \mathrm{H}_{\mathrm{Ar}}\right), 6.22\left(\mathrm{~s}, 1 \mathrm{H}, \mathrm{H}_{\mathrm{Ar}}\right), 6.18\left(\mathrm{~d},{ }^{3} \mathrm{~J}=7.3 \mathrm{~Hz}, 1 \mathrm{H}\right.$, $\left.\mathrm{H}_{\mathrm{Ar}}\right), 6.05\left(\mathrm{~s}, 1 \mathrm{H}, \mathrm{H}_{\mathrm{Ar}}\right), 5.40\left(\mathrm{~s}, 1 \mathrm{H}, \mathrm{H}_{\mathrm{Ar}}\right), 5.36\left(\mathrm{~s}, 1 \mathrm{H}, \mathrm{H}_{\mathrm{Ar}}\right), 2.62(\mathrm{~s}$, $\left.3 \mathrm{H}, \mathrm{H}_{\text {Methyl }}\right), 2.54\left(\mathrm{~s}, 3 \mathrm{H}, \mathrm{H}_{\text {Methyl }}\right), 2.46\left(\mathrm{~s}, 6 \mathrm{H}, \mathrm{H}_{\text {Methyl }}\right), 2.34(\mathrm{~s}, 3 \mathrm{H}$, $\left.\mathrm{H}_{\text {Methyl }}\right), 2.28\left(\mathrm{~m}, 6 \mathrm{H}, \mathrm{H}_{\text {Methyl }}\right), 2.18\left(\mathrm{~m}, 9 \mathrm{H}, \mathrm{H}_{\text {Methyl }}\right), 2.10(\mathrm{~s}, 3 \mathrm{H}$, $\left.\mathrm{H}_{\text {Methyl }}\right), 1.83\left(\mathrm{~s}, 3 \mathrm{H}, \mathrm{H}_{\text {Methyl }}\right), 1.75\left(\mathrm{~s}, 3 \mathrm{H}, \mathrm{H}_{\text {Methyl }}\right), 1.70(\mathrm{~s}, 3 \mathrm{H}$, $\mathrm{H}_{\text {Methyl }}$ ), 1.65 (s, 3H, $\mathrm{H}_{\text {Methyl }}$ ), 1.23 (s, 3H, $\left.\mathrm{H}_{\text {Methyl }}\right), 1.13$ (s, 3H, $\left.\mathrm{H}_{\text {Methyl }}\right), 0.53\left(\mathrm{~s}, 3 \mathrm{H}, \mathrm{H}_{\text {Methyl }}\right) .{ }^{13} \mathrm{C}\left\{{ }^{1} \mathrm{H}\right\} \operatorname{NMR}(150.88 \mathrm{MHz}, 300 \mathrm{~K}$, THF- $\left.d_{8}\right): \delta(\mathrm{ppm}) 244.2\left(\mathrm{~s}, \mathrm{C}_{\mathrm{CN}}\right), 235.5\left(\mathrm{~s}, \mathrm{C}_{\mathrm{CN}}\right), 208.7\left(\mathrm{~s}, \mathrm{C}_{\mathrm{CN}}\right)$, $191.1\left(\mathrm{~s}, \mathrm{C}_{\mathrm{CN}}\right), 142.2\left(\mathrm{~s}, \mathrm{C}_{\mathrm{Ar}}\right), 140.9\left(\mathrm{~s}, \mathrm{C}_{\mathrm{Ar}}\right), 140.5\left(\mathrm{~s}, \mathrm{C}_{\mathrm{Ar}}\right), 139.5(\mathrm{~s}$, $\left.\mathrm{C}_{\mathrm{Ar}}\right), 138.3\left(\mathrm{~s}, \mathrm{C}_{\mathrm{Ar}}\right), 138.1\left(\mathrm{~s}, \mathrm{C}_{\mathrm{Ar}}\right), 137.9\left(\mathrm{~s}, \mathrm{C}_{\mathrm{Ar}}\right), 137.4\left(\mathrm{~s}, \mathrm{C}_{\mathrm{Ar}}\right)$, $136.4\left(\mathrm{~s}, \mathrm{C}_{\mathrm{Ar}}\right), 136.2\left(\mathrm{~s}, \mathrm{C}_{\mathrm{Ar}}\right), 135.8\left(\mathrm{~s}, \mathrm{C}_{\mathrm{Ar}}\right), 135.6\left(\mathrm{~s}, \mathrm{C}_{\mathrm{Ar}}\right), 135.5(\mathrm{~s}$, $\left.\mathrm{C}_{\mathrm{Ar}}\right), 134.9\left(\mathrm{~s}, \mathrm{C}_{\mathrm{Ar}}\right), 134.7\left(\mathrm{~s}, \mathrm{C}_{\mathrm{Ar}}\right), 134.1\left(\mathrm{~s}, \mathrm{C}_{\mathrm{Ar}}\right), 134.0\left(\mathrm{~s}, \mathrm{C}_{\mathrm{Ar}}\right)$, $132.9\left(\mathrm{~s}, \mathrm{C}_{\mathrm{Ar}}\right), 132.8\left(\mathrm{~s}, \mathrm{C}_{\mathrm{Ar}}\right), 129.6\left(\mathrm{~s}, \mathrm{C}_{\mathrm{Ar}}\right), 129.5\left(\mathrm{~s}, \mathrm{C}_{\mathrm{Ar}}\right), 129.4(\mathrm{~s}$, $\left.\mathrm{C}_{\mathrm{Ar}}\right), 129.2\left(\mathrm{~s}, \mathrm{C}_{\mathrm{Ar}}\right), 128.7\left(\mathrm{~s}, \mathrm{C}_{\mathrm{Ar}}\right), 128.4\left(\mathrm{~s}, \mathrm{C}_{\mathrm{Ar}}\right), 127.9\left(\mathrm{~s}, \mathrm{C}_{\mathrm{Ar}}\right)$, $127.8\left(\mathrm{~s}, \mathrm{C}_{\mathrm{Ar}}\right), 126.1\left(\mathrm{~s}, \mathrm{C}_{\mathrm{Ar}}\right), 125.1\left(\mathrm{~s}, \mathrm{C}_{\mathrm{Ar}}\right), 29.6\left(\mathrm{~s}, \mathrm{C}_{\mathrm{Methyl}}\right), 27.0(\mathrm{~s}$, $\mathrm{C}_{\text {Methyl }}$ ), 25.4 (s, $\mathrm{C}_{\text {Methyl }}$ ), 22.0 (s, $\mathrm{C}_{\text {Methyl }}$ ), 20.8 (s, $\mathrm{C}_{\text {Methyl }}$ ), 20.5 (s, $\mathrm{C}_{\text {Methyl }}$ ), 20.2 (s, $\left.\mathrm{C}_{\text {Methyl }}\right), 20.1$ (s, $\mathrm{C}_{\text {Methyl }}$ ), 20.0 (s, $\mathrm{C}_{\text {Methyl }}$ ), 19.9 (s, $\mathrm{C}_{\text {Methyl }}$ ), 19.8 (s, $\mathrm{C}_{\text {Methyl }}$ ), 19.7 (s, $\mathrm{C}_{\text {Methyl }}$ ), 18.8 (s, $\mathrm{C}_{\text {Methyl }}$ ), 18.5 (s, $\mathrm{C}_{\text {Methyl }}$ ), 18.4 ( $\left.\mathrm{s}, \mathrm{C}_{\text {Methyl }}\right), 17.8$ (s, $\left.\mathrm{C}_{\text {Methyl }}\right), 17.5$ (s, $\mathrm{C}_{\text {Methyl }}$ ), 17.1 (s, $\left.\mathrm{C}_{\text {Methyl }}\right)$. On the basis of the ${ }^{1} \mathrm{H},{ }_{1}^{1} \mathrm{H}$-NOESY of 6 showing three different sets of methyl groups (eight in each set) it can be concluded that compound 6 can be isolated as a mixture of three isomers. IR: $\nu$ $\left(\mathrm{cm}^{-1}\right) 2914(\mathrm{w}), 2852(\mathrm{w}), 2070(\nu[\mathrm{C} \equiv \mathrm{N}], \mathrm{s}), 2022(\nu[\mathrm{C} \equiv \mathrm{N}], \mathrm{s})$, $1676(\mathrm{~m}), 1593$ (m), 1460 (m), 1370 (s), 855 (vs), 733 (vs).

Synthesis of $\left[\mathrm{K}\left(\mathrm{Et}_{2} \mathrm{O}\right)\right]_{2}\left[\mathrm{Fe}\left(\mathrm{CNAr}_{3} \mathrm{NC}\right)_{2}\right]_{2}$ (7).

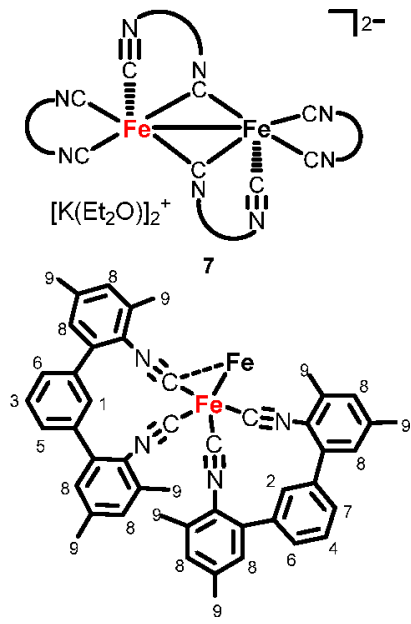

$\mathrm{KC}_{8}$ (finely ground, $104.9 \mathrm{mg}, 0.776 \mathrm{mmol}$ ) was added to a suspension of $5(215.5 \mathrm{mg}, 0.243 \mathrm{mmol})$ in THF $(25 \mathrm{~mL})$ at $-80^{\circ} \mathrm{C}$. After $30 \mathrm{~min}$ a dark orange-brown reaction solution was formed. The red solution was stirred overnight and warmed to room temperature. The solvent was removed under reduced pressure, and the brown-red residue was extracted with $\mathrm{Et}_{2} \mathrm{O}(50 \mathrm{~mL})$. After filtration the solution was concentrated in vacuo (ca. $20 \mathrm{~mL}$ ) and stored at $-30{ }^{\circ} \mathrm{C}$. Compound 7 was isolated as black crystals. Yield: $98.8 \mathrm{mg}, 46 \%$. Anal. Calcd for $\mathrm{C}_{104} \mathrm{H}_{100} \mathrm{Fe}_{2} \mathrm{~N}_{8} \mathrm{O}_{2} \mathrm{~K}_{2}(\mathrm{MW}=1683.88 \mathrm{~g} / \mathrm{mol}): \mathrm{C}, 74.18 ; \mathrm{H}$, 5.99; N, 6.65. Found: C, 74.20; H, 6.17; N, 6.78. ${ }^{1} \mathrm{H}$ NMR (400.13 $\left.\mathrm{MHz}, 300 \mathrm{~K}, \mathrm{THF}-d_{8}\right): \delta(\mathrm{ppm}) 8.96\left(\mathrm{~s}, 1 \mathrm{H}, \mathrm{H}_{1}\right.$ or $\left.\mathrm{H}_{2}\right), 8.31(\mathrm{~s}, 1 \mathrm{H}$, $\mathrm{H}_{1}$ or $\left.\mathrm{H}_{2}\right), 7.40\left(\mathrm{t},{ }^{3} \mathrm{~J}=7.5 \mathrm{~Hz}, 1 \mathrm{H}, \mathrm{H}_{3}\right.$ or $\left.\mathrm{H}_{4}\right), 7.32\left(\mathrm{t},{ }^{3} J=7.6 \mathrm{~Hz}\right.$, $1 \mathrm{H}, \mathrm{H}_{3}$ or $\left.\mathrm{H}_{4}\right), 7.26\left(\mathrm{~d},{ }^{3} \mathrm{~J}=7.6 \mathrm{~Hz}, 1 \mathrm{H}, \mathrm{H}_{5}\right.$ or $\left.\mathrm{H}_{7}\right), 7.17\left(\mathrm{~d},{ }^{3} \mathrm{~J}=7.5\right.$ $\left.\mathrm{Hz}, 2 \mathrm{H}, \mathrm{H}_{6}\right), 7.13\left(\mathrm{~d},{ }^{3} \mathrm{~J}=7.5 \mathrm{~Hz}, 1 \mathrm{H}, \mathrm{H}_{5}\right.$ or $\left.\mathrm{H}_{7}\right), 6.86\left(\mathrm{~s}, 2 \mathrm{H}, \mathrm{H}_{8}\right)$, $6.81\left(\mathrm{~s}, 1 \mathrm{H}, \mathrm{H}_{8}\right), 6.76\left(\mathrm{~s}, 1 \mathrm{H}, \mathrm{H}_{8}\right), 6.65\left(\mathrm{~s}, 1 \mathrm{H}, \mathrm{H}_{8}\right), 6.55\left(\mathrm{~s}, 2 \mathrm{H}, \mathrm{H}_{8}\right)$, $6.43\left(\mathrm{~s}, 1 \mathrm{H}, \mathrm{H}_{8}\right), 2.27\left(\mathrm{~s}, 3 \mathrm{H}, \mathrm{H}_{9}\right), 2.24\left(\mathrm{~s}, 3 \mathrm{H}, \mathrm{H}_{9}\right), 2.22\left(\mathrm{~s}, 3 \mathrm{H}, \mathrm{H}_{9}\right)$, $2.19\left(\mathrm{~s}, 6 \mathrm{H}, \mathrm{H}_{9}\right), 1.72\left(\mathrm{~s}, 9 \mathrm{H}, \mathrm{H}_{9}\right.$, overlapping with THF- $\left.d_{8}\right)$. ${ }^{13} \mathrm{C}\left\{{ }^{1} \mathrm{H}\right\}$-NMR $\left(100.61 \mathrm{MHz}, 300 \mathrm{~K}, \mathrm{THF}-d_{8}\right): \delta(\mathrm{ppm}) 297.6(\mathrm{~m}$, $\left.\mathrm{C}_{\mathrm{CN}}\right), 209.5\left(\mathrm{~m}, \mathrm{C}_{\mathrm{CN}}\right), 203.2\left(\mathrm{~m}, \mathrm{C}_{\mathrm{CN}}\right), 147.0\left(\mathrm{~m}, \mathrm{C}_{\mathrm{Ar}}\right), 142.5(\mathrm{~m}$, $\left.\mathrm{C}_{\mathrm{Ar}}\right), 140.7\left(\mathrm{~m}, \mathrm{C}_{\mathrm{Ar}}\right), 138.8\left(\mathrm{~m}, \mathrm{C}_{\mathrm{Ar}}\right), 138.6\left(\mathrm{~d}, J=3.5 \mathrm{~Hz}, \mathrm{C}_{\mathrm{Ar}}\right), 134.5$ $\left(\mathrm{d}, J=12.3 \mathrm{~Hz}, \mathrm{C}_{1}\right.$ or $\left.\mathrm{C}_{2}\right), 133.7\left(\mathrm{~s}, \mathrm{C}_{\mathrm{Ar}}\right), 133.4\left(\mathrm{~s}, \mathrm{C}_{\mathrm{Ar}}\right), 133.0(\mathrm{~s}$,
$\left.\mathrm{C}_{\mathrm{Ar}}\right), 131.5\left(\mathrm{~m}, \mathrm{C}_{8}\right), 131.0\left(\mathrm{~s}, \mathrm{C}_{\mathrm{Ar}}\right), 129.9\left(\mathrm{~s}, \mathrm{C}_{\mathrm{Ar}}\right), 129.4(\mathrm{~d}, J=15.9$ $\left.\mathrm{Hz}, \mathrm{C}_{8}\right), 129.5\left(\mathrm{~m}, \mathrm{C}_{\mathrm{Ar}}\right), 128.9\left(\mathrm{~m}_{1} \mathrm{C}_{8}\right), 128.8\left(\mathrm{~m}, \mathrm{C}_{8}\right), 128.6\left(\mathrm{~s}, \mathrm{C}_{1}\right.$ or $\left.\mathrm{C}_{2}\right), 128.1\left(\mathrm{~s}, \mathrm{C}_{\mathrm{Ar}}\right), 127.8\left(\mathrm{~d}, J=7.0 \mathrm{~Hz}, \mathrm{C}_{8}\right), 127.5(\mathrm{~d}, J=6.0 \mathrm{~Hz}$, $\left.\mathrm{C}_{6}\right), 127.2\left(\mathrm{~s}, \mathrm{C}_{3}\right.$ or $\left.\mathrm{C}_{4}\right), 126.8\left(\mathrm{~s}, \mathrm{C}_{5}\right.$ or $\left.\mathrm{C}_{7}\right), 126.5\left(\mathrm{~s}, \mathrm{C}_{5}\right.$ or $\left.\mathrm{C}_{7}\right)$, $125.6\left(\mathrm{~s}, \mathrm{C}_{6}\right), 20.2\left(\mathrm{~m}, \mathrm{C}_{9}\right), 20.0\left(\mathrm{~m}, \mathrm{C}_{9}\right), 19.7\left(\mathrm{~m}, \mathrm{C}_{9}\right), 18.8\left(\mathrm{~m}, \mathrm{C}_{9}\right)$. IR: $\nu\left(\mathrm{cm}^{-1}\right) 2968(\mathrm{w}), 2912(\mathrm{w}), 2853(\mathrm{w}), 1982(\nu[\mathrm{C} \equiv \mathrm{N}], \mathrm{w})$, $1961(\nu[\mathrm{C} \equiv \mathrm{N}], \mathrm{w}), 1765$ (br m), $1602(\mathrm{w}), 1514(\mathrm{~m}), 1456(\mathrm{~m})$, 1381 (m), 1210 (m), 855 (vs), 744 (vs), 534 (vs).

\section{ASSOCIATED CONTENT}

\section{Supporting Information}

The Supporting Information is available free of charge at https://pubs.acs.org/doi/10.1021/acs.organomet.1c00042.

NMR and IR spectroscopic data of 1-7, crystallographic data for 1-7, spectroelectrochemical data of 2, 4, and 7, and details of the density functional theory calculation of 6 (PDF)

Cartesian coordinates for the calculated structure (XYZ)

\section{Accession Codes}

CCDC 2056040-2056046 contain the supplementary crystallographic data for this paper. These data can be obtained free of charge via www.ccdc.cam.ac.uk/data_request/cif, or by emailing data_request@ccdc.cam.ac.uk, or by contacting The Cambridge Crystallographic Data Centre, 12 Union Road, Cambridge CB2 1EZ, UK; fax: +44 1223336033.

\section{AUTHOR INFORMATION}

\section{Corresponding Authors}

Robert Wolf - Institute of Inorganic Chemistry, University of Regensburg, 93040 Regensburg, Germany; (1) orcid.org/ 0000-0003-4066-6483; Email: robert.wolf@ur.de

Oliver Reiser - Institute of Organic Chemistry, University of Regensburg, 93040 Regensburg, Germany; (1) orcid.org/ 0000-0003-1430-573X; Email: oliver.reiser@ur.de

\section{Authors}

Marion Till - Institute of Inorganic Chemistry, University of Regensburg, 93040 Regensburg, Germany

John A. Kelly - Institute of Inorganic Chemistry, University of Regensburg, 93040 Regensburg, Germany

Christoph G. P. Ziegler - Institute of Inorganic Chemistry, University of Regensburg, 93040 Regensburg, Germany

Tianao Guo - Institute of Inorganic Chemistry, University of Stuttgart, 70569 Stuttgart, Germany

Mark R. Ringenberg - Institute of Inorganic Chemistry, University of Stuttgart, 70569 Stuttgart, Germany; (1) orcid.org/0000-0001-7585-5757

Eugen Lutsker - Institute of Organic Chemistry, University of Regensburg, 93040 Regensburg, Germany

Complete contact information is available at:

https://pubs.acs.org/10.1021/acs.organomet.1c00042

\section{Notes}

The authors declare no competing financial interest.

\section{ACKNOWLEDGMENTS}

Funding by the European Research Council (ERC CoG 772299) is gratefully acknowledged. We thank Marc Schlosser and Willibald Stockerl for valuable assistance. This paper is dedicated to F. Ekkehardt Hahn, who has made many important contributions to the coordination chemistry of isonitriles. 


\section{REFERENCES}

(1) Lieke, W. Ueber das Cyanallyl. Justus Liebigs Ann. Chem. 1859, $112,316-321$.

(2) (a) Meyer, E. Neue Versuche mit Cyansilber. J. Prakt. Chem. 1866, 67, 147-153. (b) Gautier, A. Ueber die Einwirkung des Chlorwasserstoffs ua auf das Aethyl- und Methylcyanür. Justus Liebigs Ann. Chem. 1867, 142, 289-294. (c) Hofmann, A. W. Ueber eine neue Reihe von Homologen der Cyanwasserstoffsäure. Justus Liebigs Ann. Chem. 1867, 144, 114-120. (d) Gautier, A. Ueber eine neue Reihe von Verbindungen, welche mit den CyanwasserstoffsäureAethern isomer sind. Justus Liebigs Ann. Chem. 1868, 146, 119-124. (e) Ugi, I.; Meyr, R. Neue Darstellungsmethode für Isonitrile. Angew. Chem. 1958, 70, 702-703. (f) Ugi, I. Isonitrile Chemistry; Academic Press: 1971.

(3) Malatesta, L. Isocyanide Complexes of Metals. Prog. Inorg. Chem. 2007, 283-379.

(4) Elschenbroich, C. Organometallchemie; Teubner: 2008.

(5) Knorn, M.; Lutsker, E.; Reiser, O. Isonitriles as supporting and non-innocent ligands in metal catalysis. Chem. Soc. Rev. 2020, 49, $7730-7752$.

(6) Knorn, M.; Rawner, T.; Czerwieniec, R.; Reiser, O. [Copper(phenanthroline)(bisisonitrile) $]^{+}$-Complexes for the Visible-LightMediated Atom Transfer Radical Addition and Allylation Reactions. ACS Catal. 2015, 5, 5186-5193.

(7) Büldt, L. A.; Guo, X.; Prescimone, A.; Wenger, O. S. A Molybdenum(0) Isocyanide Analogue of $\mathrm{Ru}\left(2,2^{\prime} \text {-Bipyridine }\right)_{3}{ }^{2+}: \mathrm{A}$ Strong Reductant for Photoredox Catalysis. Angew. Chem., Int. Ed. 2016, 55, 11247-11250.

(8) Larsen, C. B.; Wenger, O. S. Photophysics and Photoredox Catalysis of a Homoleptic Rhenium(I) Tris(diisocyanide) Complex. Inorg. Chem. 2018, 57, 2965-2968.

(9) Wenger, O. S. Photoactive Complexes with Earth-Abundant Metals. J. Am. Chem. Soc. 2018, 140, 13522-13533.

(10) Zhou, W. J.; Wu, X. D.; Miao, M.; Wang, Z. H.; Chen, L.; Shan, S. Y.; Cao, G. M.; Yu, D. G. Light Runs Across Iron Catalysts in Organic Transformations. Chem. - Eur. J. 2020, 26, 15052-15064.

(11) Duncan Lyngdoh, R. H.; Schaefer, H. F.; King, R. B. Metalmetal (MM) bond distances and bond orders in binuclear metal complexes of the first-row transition metals titanium through zinc. Chem. Rev. 2018, 118, 11626-11706.

(12) (a) Fehlhammer, W. P.; Mayr, A.; Kehr, W. Isocyanide- und Heteroallen-verbrückte Metallkomplexe. J. Organomet. Chem. 1980, 197, 327-334. (b) Coville, N. J.; Albers, M. O.; Singleton, E. An Investigation of the Reaction Between $\left[\left\{\mathrm{Fe}\left(\eta^{5}-\mathrm{C}_{5} \mathrm{H}_{5}\right)(\mathrm{CO})_{2}\right\}_{2}\right]$ and Aryl Isonitriles. J. Chem. Soc., Dalton Trans. 1982, 1389-1391.

(13) Ruiz, R.; Riera, V.; Vivanco, M.; Garcia-Granda, S.; Pertierra, P. A Homoleptic (Aryl Isocyanide)Iron(0) Dimer. X-ray Structure Determination of Nonakis(phenyl isocyanide)diiron. Organometallics 1992, 11, 2734-2736.

(14) (a) Murray, J. B.; Nicholson, B. K.; Whitton, A. J. Multisubstituted isonitrile and mixed ligand derivatives of $\mathrm{Fe}_{3}(\mathrm{CO})_{12}$; the crystal structure of $\mathrm{Fe}_{3}(\mathrm{CO})_{10}\left(\mathrm{CNBu}^{t}\right)_{2}$. J. Organomet. Chem. 1990, 385, 91-100. (b) Decker, C.; Henderson, W.; Nicholson, B. K. Reactions of isonitriles with $\left[\mathrm{Fe}_{3}(\mathrm{CO})_{12}\right]$ and $\left[\mathrm{Ru}_{3}(\mathrm{CO})_{12}\right]$ monitored by electrospray mass spectrometry; structural characterization of $\left[\mathrm{Fe}_{3}(\mathrm{CO})_{10}(\mathrm{CNPh})_{2}\right]$ and $\left[\mathrm{Ru}_{4}(\mathrm{CO})_{11}\left(\mu_{3}-\eta^{2}-\mathrm{CNPh}\right)\right]$. $J$. Organomet. Chem. 2004, 689, 1691-1701.

(15) Brennessel, W. W.; Ellis, J. E. $\left[\mathrm{Fe}(\mathrm{CNXyl})_{4}\right]^{2-}$ : An Isolable and Structurally Characterized Homoleptic Isocyanide-metalate Dianion. Angew. Chem., Int. Ed. 2007, 46, 598-600.

(16) Mokhtarzadeh, C. C.; Margulieux, G. W.; Carpenter, A. E.; Weidemann, N.; Moore, C. E.; Rheingold, A. L.; Figueroa, J. S. Synthesis and Protonation of an Encumbered Iron Tetra-isocyanide Dianion. Inorg. Chem. 2015, 54, 5579-5587.

(17) Drance, M. J.; Sears, J. D.; Mrse, A. M.; Moore, C. E.; Rheingold, A. L.; Neidig, M. L.; Figueroa, J. S. Terminal coordination of diatomic boron monofluoride to iron. Science 2019, 363, 12031205.
(18) Barybin, M. V.; Meyers, J. J., Jr.; Neal, B. M. Renaissance of Isocyanoarenes as Ligands in Low-Valent Organometallics. In Isocyanide Chemistry-Applications in Synthesis and Material Science; Nenajdenko, V., Ed.; Wiley-VCH: Weinheim, Germany, 2012; pp 493-529.

(19) Hahn, F. E. The Coordination Chemistry of Multidentate Isocyanide Ligands. Angew. Chem., Int. Ed. Engl. 1993, 32, 650-665. (20) (a) Angelici, R. J.; Quick, M. H.; Kraus, G. A.; Plummer, D. T. Synthesis of Chelating Bidentate Isocyano and Cyano Ligands and Their Metal Complexes. Inorg. Chem. 1982, 21, 2178-2184. (b) Kargol, J. A.; Angelici, R. J. Iron(II) Complexes with the Chelating Bidentate Isonitrile Ligand DiNC. Inorg. Chim. Acta 1983, $68,127-130$.

(21) Sakata, K.; Fujitsu, T.; Tajiri, H.; Masatsugu, M.; Hashimoto, M. Syntheses and Characterization of Iron(II), Copper(I) and Rhodium(I) Complexes with a Chelating Bidentate Isonitrile Ligand. Synth. React. Inorg. Met.-Org. Chem. 1994, 24, 1509-1522.

(22) Sakata, K.; Urabe, K.; Hashimoto, M.; Yanagi, T.; Tsuge, A.; Angelici, R. J. Synthesis and Spectral Properties of Iron(II), Copper(I), Silver(I), and Palladium(II) Complexes of a Bidentate Diisonitrile. Synth. React. Inorg. Met.-Org. Chem. 2003, 33, 11-22.

(23) Naik, A.; Maji, T.; Reiser, O. Iron(II)-bis(isonitrile) complexes: novel catalysts in asymmetric transfer hydrogenations of aromatic and heteroaromatic ketones. Chem. Commun. 2010, 46, 4475-4477.

(24) Selected examples: (a) Wolf, R.; Ghavtadze, N.; Weber, K.; Schnöckelborg, E.-M.; de Bruin, B.; Ehlers, A. W.; Lammertsma, K. P$\mathrm{C}$ dichotomy: divergent iron (-I)-mediated alkyne and phosphaalkyne cyclooligomerisations. Dalton Trans. 2010, 39, 1453-1456. (b) Wolf, R.; Schnöckelborg, E.-M. A reactive iron naphthalene complex provides convenient access to the $\mathrm{Cp}^{*} \mathrm{Fe}^{-}$synthon $\left(\mathrm{Cp}^{*}=\mathrm{C}_{5} \mathrm{H}_{5}\right)$. Chem. Commun. 2010, 46, 2832-2834. (c) Schnöckelborg, E.-M.; Khusniyarov, M. M.; de Bruin, B.; Hartl, F.; Langer, T.; Eul, M.; Schulz, S.; Pöttgen, R.; Wolf, R. Unraveling the Electronic Structures of Low-Valent Naphthalene and Anthracene Iron Complexes: X-ray, Spectroscopic, and Density Functional Theory Studies. Inorg. Chem. 2012, 51, 6719-6730. (d) Maier, T. M.; Gawron, M.; Coburger, P.; Bodensteiner, M.; Wolf, R.; van Leest, N. P.; de Bruin, B.; Demeshko, S.; Meyer, F. Low-Valence Anionic $\alpha$-Diimine Iron Complexes: Sythesis, Characterization, and Catalytic Hydroboration Studies. Inorg. Chem. 2020, 59, 16035-16052.

(25) Selected examples: (a) Rezaei Rad, B.; Herrmann, D.; Lescop, C.; Wolf, R. A tetradentate metalloligand: synthesis and coordination behaviour of a 2-pyridyl-substituted cyclobutadiene iron complex. Dalton Trans. 2014, 43, 4247-4250. (b) Rezaei Rad, B.; Chakraborty, U.; Mühldorf, B.; Bodensteiner, M.; Sklorz, J. A. W.; Müller, C.; Wolf, R. Synthesis, Structure, and Reactivity of Pentamethylcyclopentadienyl 2,4,6-Triphenylphsophinine Iron Complexes. Organometallics 2015, 34, 622-635. (c) Büschelberger, P.; Gärtner, D.; ReyesRodriguez, E.; Kreyenschmidt, F.; Koszinowski, K.; Jacobi von Wangelin, A.; Wolf, R. Alkene Metalates as Hydrogenation Catalysts. Chem. - Eur. J. 2017, 23, 3139-3151. (d) Chakraborty, U.; Leitl, J.; Mühldorf, B.; Bodensteiner, M.; Pelties, S.; Wolf, R. Mono- and dinuclear tetraphosphabutadiene ferrate anions. Dalton. Trans. 2018, 47, 3693-3697. (e) Leitl, J.; Marquardt, M.; Coburger, P.; Scott, D. J.; Streitferdt, V.; Gschwind, R. M.; Müller, C.; Wolf, R. Facile C = O Bond Splitting of Carbon Dioxide Induced by Metal-Ligand Cooperativity in a Phosphinine Iron(0) Complex. Angew. Chem., Int. Ed. 2019, 58, 15407-15411.

(26) Warnock, G. F.; Cooper, N. J. The first transition-metal isonitrilate: synthesis and characterization of cobalt complex $\mathrm{K}[\mathrm{Co}-$ (2,6- $\left.\left.\mathrm{Me}_{2} \mathrm{C}_{6} \mathrm{H}_{3} \mathrm{NC}\right)_{4}\right]$. Organometallics 1989, 8, 1826-1827.

(27) (a) Brill, R. Z. Krist. 1931, 72, 36. (b) Sheline, R. K. The Spectra and Structure of Iron Carbonyl. II. Iron Tetracarbonyl. J. Am. Chem. Soc. 1951, 73, 1615. (c) Dahl, L. F.; Rundle, R. E. Polynuclear Metal Carbonyl. III. Infrared Analysis of Iron Tetracarbonyl. J. Chem. Phys. 1957, 27, 323-324. (d) Dahl, L. F.; Blount, J. F. The Probable Structure of $\mathrm{Fe}_{3}(\mathrm{CO})_{12}$ as Obtained from the Structure of $\mathrm{HFe}_{3}(\mathrm{CO})_{11}{ }^{-}$. Inorg. Chem. 1965, 4, 1373-1375. (e) Wei, C. H.; Dahl, L. F. Molecular Structure of Triiron Dodecacarbonyl and 
Tetracobalt Dodecacarbonyl. J. Am. Chem. Soc. 1966, 88, 1821-182. (f) Wei, C. H.; Dahl, L. F. Triiron Dodecacarbonyl: An Analysis of Its Stereochemistry. J. Am. Chem. Soc. 1969, 91, 1351-1361. (g) Cotton, F. A.; Troup, J. M. Further Refinement of the Molecular Structure of Triiron Dodecacarbonyl. J. Am. Chem. Soc. 1974, 96, 4155-4159. (h) Braga, D.; Farrugia, L.; Grepioni, F.; Johnson, B. F. G. On the molecular structure of $\left[\mathrm{Fe}_{3}(\mathrm{CO})_{12}\right]$ in the solid state. J. Organomet. Chem. 1994, 464, C39-C41. (i) Braga, D.; Grepioni, F.; Tedesco, E.; Calhorda, M. J.; Lopes, P. E. M. Molecular Structure and Crystal Structure Generation for $\left[\mathrm{Fe}_{3}(\mathrm{CO})_{12}\right]$. J. Chem. Soc., Dalton Trans. 1995, 3297-3306. (j) Hunstock, E.; Mealli, C.; Calhorda, M. J.; Reinhold, J. Molecular Structures of $\mathrm{M}_{2}(\mathrm{CO})_{9}$ and $\mathrm{M}_{3}(\mathrm{CO})_{12}(\mathrm{M}=$ $\mathrm{Fe}, \mathrm{Ru}, \mathrm{Os})$ : New Theoretical Insights. Inorg. Chem. 1999, 38, 50535060.

(28) Brennessel, W. W.; Kucera, B. E.; Young, V. G., Jr; Ellis, J. E. Crystal structure and spectroscopic characterization of $\mathrm{MBr}_{2}(\mathrm{CNXyl})_{\mathrm{n}}(\mathrm{M}=\mathrm{Fe}$ and Co, $\mathrm{n}=4 ; \mathrm{M}=\mathrm{Ni}, \mathrm{n}=2 ; \mathrm{Xyl}=2,6-$ dimethylphenyl), and of formally zero-valent iron as a cocrystal of $\mathrm{Fe}(\mathrm{CNXyl})_{5}$ and $\mathrm{Fe}_{2}(\mathrm{CNXyl})_{9}$. Acta Crystallogr., Sect. C 2019, C75, $1118-1127$.

(29) Krejcik, M.; Danek, M.; Hartl, F. Simple construction of an infrared optically transparent thin layer electrochemical cell. Applications to the redox reactions of ferrocene, $\mathrm{Mn}_{2}(\mathrm{CO})_{10}$ and $\mathrm{Mn}(\mathrm{CO})_{3}$ (3,5-di-t-butyl-catecholate $)^{-}$. J. Electroanal. Chem. Interfacial Electrochem. 1991, 317, 179-187.

(30) El Murr, N.; Chaloyard, A. Redox properties of iron carbonyl complexes. Inorg. Chem. 1982, 21, 2206-2208.

(31) Hubbard, J. L.; McVicar, W. K. Facile conversion of $\left(\eta^{5-} \mathrm{C}_{5} \mathrm{R}_{5}\right) \mathrm{M}(\mathrm{CO})_{2}$-halide complexes to halomethyl, alkoxymethyl, and cyanomethyl derivatives $\left(\mathrm{R}=\mathrm{H}, \mathrm{CH}_{3} ; \mathrm{M}=\mathrm{Fe}, \mathrm{Ru}\right.$; halide $=\mathrm{Cl}$, $\mathrm{Br}, \mathrm{I})$. J. Organomet. Chem. 1992, 429, 369-378.

(32) (a) Mills, O. S. Studies of some carbon compounds of the transition metals. I. The crystal structure of dicyclopentadienyldiiron tetracarbonyl. Acta Crystallogr. 1958, 11, 620-623. (b) Mills, O. S.; Nice, J. P. Carbon compounds of the transition metals: V. The structure of bis(cyclopentadienyldicarbonyl-ruthenium). J. Organomet. Chem. 1967, 9, 339.

(33) Jonas, K.; Klussmann, P.; Goddard, R. Pentamethylcyclopentadienylbis(ethen)eisen - ein 17 e-Halbsandwichkomp-lex mit leicht verdrängbaren Ethenliganden. Z. Naturforsch., B: J. Chem. Sci. 1995, 50, 394.

(34) Torubaev, Y. V.; Skabitskiy, I. V.; Rusina, P.; Pasynskii, A. A.; Rai, D. K.; Singh, A. Organometallic halogen bond acceptors: directionality, hybrid cocrystals precipitation, and blueshifted CO ligand vibrational band. CrystEngComm 2018, 20, 2258-2266.

(35) Hallam, B. F.; Mills, O. S.; Pauson, P. L. Dicyclopentadienyldiirontetracarbonyl. J. Inorg. Nucl. Chem. 1955, 1, 313-316.

(36) Bryan, R. F.; Greene, P. T.; Newlands, M. J.; Field, D. S. MetalMetal Bonding in Coordination Complexes. Part X. Preparation, Spectroscopic Properties, and Crystal Structure of the cis-Isomer of $\mathrm{Di}-\mu$-carbonyl-dicarbonyldi- $\pi$-cyclopentadienyldi-iron (Fe-Fe). $J$. Chem. Soc. A 1970, 0, 3068-3074.

(37) (a) Bullitt, J. G.; Cotton, F. A.; Marks, T. J. Structural and Dynamic Properties of the Pentahaptocyclopentadienylmetal Dicarbonyl Dimers. Inorg. Chem. 1972, 11, 671-676. (b) Vitale, M.; Lee, K. K.; Hemann, C. F.; Hille, R.; Gustafson, T. L.; Bursten, B. E. Resonance Raman Studies of $\left[\mathrm{CpFe}(\mathrm{CO})_{2}\right]_{2}$ and $\left[\mathrm{Cp} * \mathrm{Fe}(\mathrm{CO})_{2}\right]_{2}$ : A Probe of Photoreactive States and Intermedites. J. Am. Chem. Soc. 1995, 117, 2286-2296. (c) Anna, J. M.; King, J. T.; Kubarych, K. J. Multiple Structures and Dynamics of $\left[\mathrm{CpRu}(\mathrm{CO})_{2}\right]_{2}$ and $[\mathrm{CpFe}-$ $\left.(\mathrm{CO})_{2}\right]_{2}$ in Solution Revealed with Two-Dimensional Infrared Spectroscopy. Inorg. Chem. 2011, 50, 9273-9283.

(38) King, R. B.; Bisnette, M. B. Organometallic Chemistry of the Transition Metals XXI. Some $\pi$-Pentamethylcyclopenta-dienyl Derivates of various Transition Metals. J. Organomet. Chem. 1967, 8, 287-297.

(39) Teller, R. G.; Williams, J. M. Crystals and molecular structure of bis[dicarbonyl $\left(\pi\right.$-pentamethylcyclopentadienyl) iron], $\left(\eta^{5}\right.$ -
$\left.\mathrm{C}_{5} \mathrm{Me}_{5}\right)_{2} \mathrm{Fe}_{2}(\mathrm{CO})_{4}$, and structural comparisons with the nonmethylated analog. Inorg. Chem. 1980, 19, 2770-2773.

(40) (a) Poliakoff, M; Turner, J. J. Infrared Spectrum and Photochemistry of Di-iron Enneacarbonyl in Matrices at 20K: Evidence for the Formation of $\mathrm{Fe}_{2}(\mathrm{CO})_{8}$. J. Chem. Soc. A 1971, 2403-2410. (b) Bertini, L.; Bruschi, M.; De Gioia, L.; Fantucci, P. Structure and Energetics of $\mathrm{Fe}_{2}(\mathrm{CO})_{8}$ Singlet and Triplet Electronic States. J. Phys. Chem. A 2007, 111, 12152-12162.

(41) Safa, M.; Dong, Z.; Song, Y.; Huang, Y. Examining the structural changes in $\mathrm{Fe}_{2}(\mathrm{CO})_{9}$ under high external pressures by Raman spectroscopy. Can. J. Chem. 2007, 85, 866-872.

(42) Hieber, W.; Brendel, G. Entstehung mehrkerniger Carbonylferrate aus mehrkernigen Eisencarbonylen. Z. Anorg. Allg. Chem. 1957, 289, 324-337.

(43) Chen, X.; Lingam, H. K.; Meyers, E. A.; Shore, S. G. Structures of DMF potassium and sodium salts of $\left[\mathrm{Fe}(\mathrm{CO})_{4}\right]^{2-}$ and $\left[\mathrm{M}_{2}(\mathrm{CO})_{8}\right]^{2-}(\mathrm{M}=\mathrm{Fe}, \mathrm{Ru})$. J. Organomet. Chem. 2012, 721-722, 137-143.

(44) Neumüller, B.; Petz, W. Reactions of $\mathrm{Fe}_{2}(\mathrm{CO})_{9}$ with Lithium: Preparation and Structures of Compounds with Strong Ion Pairing. Organometallics 2001, 20, 163-170.

(45) (a) Sheldrick, G. M. SADABS; Bruker AXS: Madison, USA, 2007. (b) CrysAlisPro, Scale3 Abspack; Rigaku Oxford Diffraction: 2019.

(46) Clark, R. C.; Reid, J. S. The analytical calculation of absorption in multifaceted crystals. Acta Crystallogr., Sect. A: Found. Crystallogr. 1995, 51, 887-897.

(47) Dolomanov, O. V.; Bourhis, L. J.; Gildea, R. J.; Howard, J. A. K.; Puschmann, H. Complete Structure Solution, Refinement and Analysis Program. J. Appl. Crystallogr. 2009, 42, 339-341.

(48) Sheldrick, G. M. Crystal structure refinement with SHELXL. Acta Crystallogr., Sect. A: Found. Adv. 2015, 71, 3-8.

(49) Sheldrick, G. M. SHELXT-Integrated space-group and crystalstructure determination. Acta Crystallogr., Sect. C: Struct. Chem. 2015, $71,3-8$.

(50) Sheldrick, G. M. A short history of SHELX. Acta Crystallogr., Sect. A: Found. Crystallogr. 2008, 64, 112-122. 